\title{
Abortion, family planning, and population policy: Prospects for the common-ground approach
}

Dennis Hodgson

Fairfield University, hodgson@fairfield.edu

Follow this and additional works at: https://digitalcommons.fairfield.edu/sociologyandanthropologyfacultypubs

Archived with permission from the copyright holder.

Copyright 2009 Wiley and Population Council.

Link to the journal homepage: (http://wileyonlinelibrary.com/journal/padr)

\section{Peer Reviewed}

\section{Repository Citation}

Hodgson, Dennis, "Abortion, family planning, and population policy: Prospects for the common-ground approach" (2009). Sociology \& Anthropology Faculty Publications. 37.

https://digitalcommons.fairfield.edu/sociologyandanthropology-facultypubs/37

\section{Published Citation}

Hodgson, Dennnis. "Abortion, family planning, and population policy: Prospects for the common-ground approach" Population and Development Review 35, no. 3 (September 2009): 479-518.

This item has been accepted for inclusion in DigitalCommons@Fairfield by an authorized administrator of DigitalCommons@Fairfield. It is brought to you by DigitalCommons@Fairfield with permission from the rightsholder(s) and is protected by copyright and/or related rights. You are free to use this item in any way that is permitted by the copyright and related rights legislation that applies to your use. For other uses, you need to obtain permission from the rights-holder(s) directly, unless additional rights are indicated by a Creative Commons license in the record and/or on the work itself. For more information, please contact digitalcommons@fairfield.edu. 


\title{
Abortion, Family Planning, and Population Policy: Prospects for the Common-Ground Approach
}

\author{
DENNIS HODGSON
}

OVER TIME and in different places, those formulating population policy have produced widely divergent assessments of induced abortion: a murderous act that ends a human life; a treasonous act damaging to the interests of the state; an injurious act threatening the health and future fertility of a woman; an inefficient means of birth control that should be replaced by modern contraceptives; an efficient means of birth control that can contribute significantly to both individual and societal fertility control; a necessary option to deal with occasional contraceptive failure; a health-promoting act when provided by competent medical personnel; and an individual woman's right that should be protected by the state. For the past several decades those engaged in shaping the Program of Action documents at international conferences on population have muted their voices when the topic of abortion has been raised. Great care has been taken to define "family planning" and "birth control" in ways that explicitly exclude abortion, although a strong semantic case could be made that abortion is in the service of both. Any advocacy of antinatalist population policies in such documents has included proscriptions on the use of abortion as a means of family planning and on claims that expanding access to contraception will reduce the number of abortions. This "common-ground" compromise on abortion has remained in place even as the extent of the practice of induced abortion has become more widely known, as the role induced abortion plays in fertility transitions has become better understood, and as more women have gained enhanced access to legal abortion that permits its use as a means of fertility control. This article has three goals: to examine the appropriateness of these directives with respect to what is currently known about the relationship between abortion, family planning, and population policy; to trace how this "contraception-only" definition of family planning became de rigueur 
at international population conferences; and to explore the prospects for the emergence of a more appropriate common-ground approach.

\section{The interplay of abortion, family planning, and population policy}

Accurate estimates of both legal and illegal abortions are difficult to make. Even in countries where legal abortions are easy to obtain, some procedures usually take place in private settings and go unreported in national statistics. In countries where access to legal abortion is highly restricted, the vast majority of abortions are illegal and do not appear in official statistics. The number of illegal abortions has to be estimated from a combination of survey data, hospital-based studies, and analyses of maternal mortality rates. A research team at the Guttmacher Institute has been regularly compiling statistics on worldwide legal abortions. Their latest report (Sedgh et al. 2007b) estimates that 22 million legal abortions occurred in 2003 and includes countryspecific data. The five countries with the most legal abortions were: China $(7,215,000)$, India $(2,400,000)$, Russia $(1,504,000)$, United States $(1,287,000)$, and Vietnam $(540,000) .{ }^{1}$ For the past 25 years the World Health Organization has maintained a database on unsafe and illegal abortions and has published worldwide estimates on a regular basis. Its latest estimates can be found in the 5th edition of Unsafe Abortion (WHO 2007). It estimates that 20 million illegal abortions occurred in 2003 and presents estimates for regions but not for countries. ${ }^{2}$ A combined effort by members of the Guttmacher and WHO research teams (Sedgh et al. 2007a: 1342) presents sub-regional estimates of both legal and illegal abortions occurring in 2003.

According to these best estimates, of the 210 million pregnancies in the world each year, approximately 130 million result in live births, 38 million in spontaneous abortions and still births, 22 million in legal abortions, and 20 million in illegal abortions (WHO 2007: 1-4). About 80 million of these annual pregnancies are estimated to be unintended, so induced abortion, legal and illegal, currently is being used to end somewhat more than half the world's unintended pregnancies.

Although women are clearly using abortion as a major means of controlling their fertility, since the 1984 Mexico City International Conference on Population (United Nations 1984: 767) all international population conferences' Program of Action documents have contained the same policy directive: "...in no case should [abortion] be promoted as a method of family planning." Section 8.25 of the 1994 Cairo International Conference on Population and Development's Programme of Action included this directive and additionally characterized family planning as an anti-abortion endeavor: "All governments and relevant intergovernmental and non-governmental organizations are urged ... to reduce the recourse to abortion through expanded and improved 
family-planning services." Those seeking a consensus program of action at Cairo took this position in order to sidestep entanglement in a bitter debate over the morality of abortion. The hope was that all participants might unite behind a common-ground effort to improve access to modern contraceptives that would simultaneously enhance fertility control and reduce the "problem" of abortion. Both the Cairo+5 and the Cairo+10 documents (UN 1999: 625; UNFPA 2005: 80-81) continue this strategy with only minor modifications. A similar tension exists in World Health Organization forums and documents. In its latest edition of Unsafe Abortion (WHO 2007: 20) the WHO still recommends that governments "reduce the recourse to abortion by expanding and improving family planning services," language that is nearly identical to that found in the Cairo Programme of Action. Despite this international support for a contraception-only approach to family planning, an increasing number of countries permit abortions "on request" or for "economic or social reasons," the result of a worldwide liberalization of abortion laws that began in the late 1960s.

The following analysis of contemporary abortion policies uses the United Nations database, World Population Policies 2007 (United Nations 2008), but excludes countries with populations of less than 100,000 from the analysis. The UN Population Division has maintained a country-specific database on abortion policies for over a decade, examining each country's criminal code as well as any public health or medical ethics codes that affect the application of abortion laws in particular situations. A three-volume work, Abortion Policies: A Global Review (United Nations 2002), contains treatments of the specific grounds on which each country permits abortion, duration-of-pregnancy limitations for specific grounds, a history of the country's abortion policies, and an assessment of its implementation of those policies. Seven standard grounds are used to categorize when countries permit abortion: to save the life of the woman, to preserve physical health, to preserve mental health, rape or incest, fetal impairment, for economic or social reasons, and on request. Every country places some duration-of-pregnancy limitations on when legal abortions are permitted, except for cases where the woman's life is in danger. In all cases where countries permit abortion on request or for economic or social reasons, the permission exists for a limited gestational period, in the range of 10 to 24 weeks. Denmark's abortion regulations are an example of such distinctions (United Nations 2002: 124-125). A woman can obtain an abortion on request during the first 12 weeks of pregnancy, but thereafter abortion is permitted only when "necessary to avert a risk to her life or of serious deterioration to her physical or mental health, and this risk is based solely or principally on circumstances of a medical character," or when approved by a committee. The committee usually grants permission if the pregnancy resulted from a criminal act, or if significant fetal abnormality exists, or if the mother is not likely to be able to provide care to a child because 
of her mental or physical disability or extreme youth. Either by limiting the allowable reasons for abortion or by offering greater protection of fetal rights as the gestation period increases, all states recognize that a difference exists between abortion and contraception. Contraception and abortion are most similar in terms of state regulation in those countries permitting abortion on request or for economic or social reasons when these abortions occur within the stipulated gestational period since documentation of an economic or social reason is rarely if ever required. Although some countries permitting abortion "to preserve mental health" liberally interpret its meaning and thereby grant women relatively uncomplicated access to legal abortion, many countries permitting abortion for that reason are not so liberal in their interpretation. Therefore for this analysis having "uncomplicated access to legal abortion" is defined as living in a country that permits abortion on request or for economic or social reasons. Such permission always comes with some gestational limitations and is subject to varying specifications by national legislation. In many "uncomplicated access" countries, a woman who discovers her pregnancy late, or who has difficulty finding an abortion facility, or who cannot afford a legal abortion still might find her access anything but "uncomplicated."

The World Population Policies 2007 database contains updated UN information on each country's 2007 abortion policies, its 1996 abortion policies, its population policies with respect to size and growth, age structure and spatial distribution, fertility levels, mortality levels, and migration levels for 1976, 1986, 1996, and 2007, as well as UN estimates of each country's relevant demographic and health measures for those four years. The data in the following figures and tables come from this database, apart from the several exceptions noted in Table 1.

Governments make laws, and examining changes in the percent of countries with particular abortion policies is a meaningful way of measuring policy change. But if one uses only the country as the unit of analysis when examining the distribution of particular abortion policies, misleading policy assessments can result. The great variation in population size among countries, from 100,000 to 1.3 billion in this case, means that the percent of the world's population living under a particular abortion policy is determined more by the population sizes of countries with that policy rather than by the number of such countries. To obtain the clearest understanding of global abortion policy, one must use both countries and percent of population as units of analysis. Figures 1-6 reflect this need.

Figure 1 indicates that in 2007, 56 of the 179 countries ( 31 percent) in the world with populations of more than 100,000 permitted abortion on request and 67 countries ( 37 percent) permitted abortion for economic or social reasons. At the national level, therefore, somewhat over a third of all countries have granted women the legal right to use abortion as a means of fertility control rather than only to preserve their lives and health or as a re- 
FIGURE 1 Percent of countries permitting abortion for various reasons, 1996 and 2007

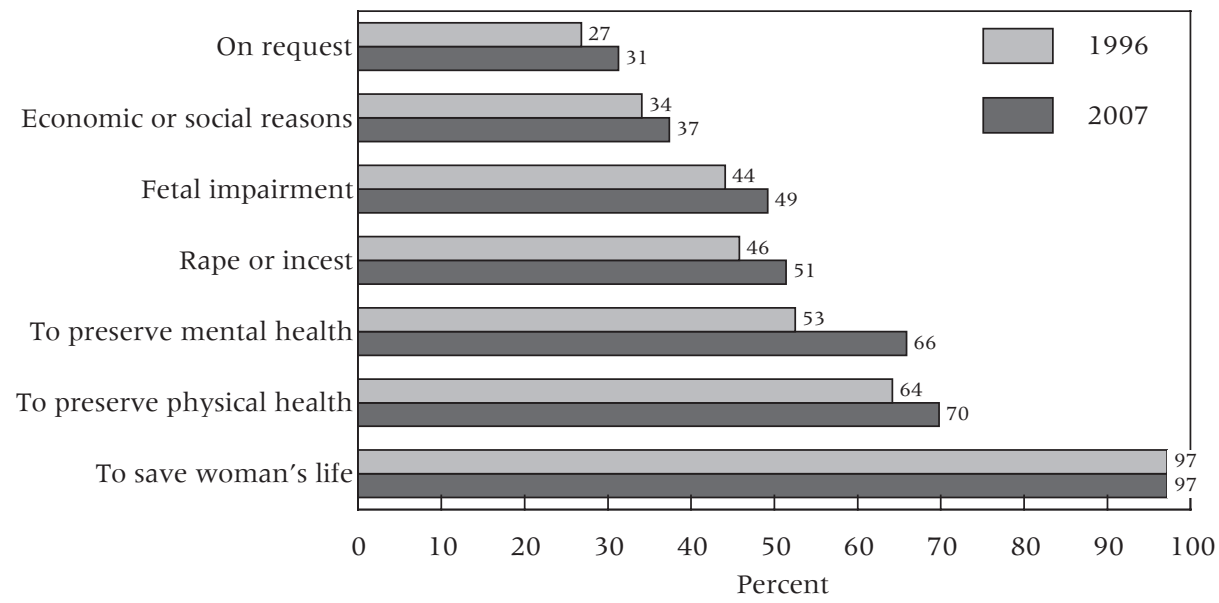

SOURCE: United Nations, World Population Policies 2007 (all countries 100,000 or more population); «http://www.un.org/esa/population/publications/wpp2007/Publication_index.htm».

sponse to fetal abnormality or sexual assault. Among countries, the general liberalization trend that began in the late 1960s has continued over the last decade. The number of countries permitting abortion for every reason, except for the nearly universally permitted reason of saving the woman's life, was greater in 2007 than in 1996. The most significant change was in the number

FIGURE 2 Percent of world's population living in countries permitting abortion for various reasons, 1996 and 2007

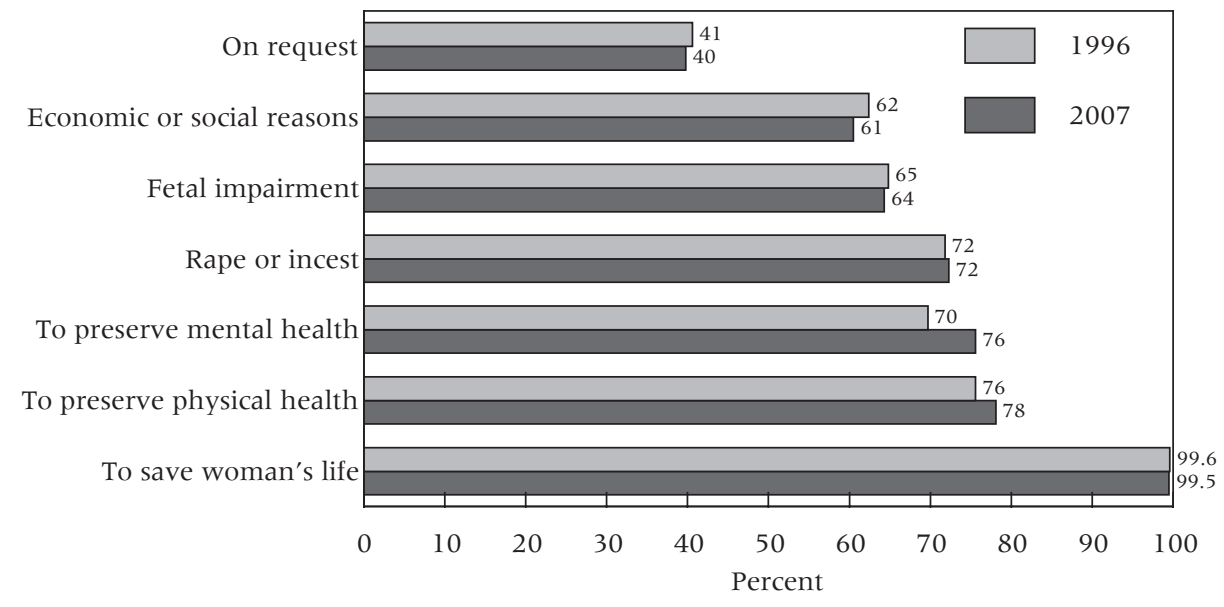

SOURCE: See Figure 1 
of countries permitting abortion to preserve mental health, increasing from 94 (53 percent) in 1996 to 118 (66 percent) in 2007.

Figure 2 changes the unit of analysis to the percent of the world population living in countries with various abortion policies. This change leads to different assessments of the distribution of abortion policies; the most notable is that from a population perspective roughly three-fifths of the world's women currently have uncomplicated access to legal abortion. Interestingly, the liberalizing trend from 1996 to 2007 that was evident in the country analysis in Figure 1 is not evident in the population analysis of Figure 2. "Uncomplicated access" percentages actually have declined somewhat from 1996 to 2007. The reason for these contrary trends lies in the fact that countries with uncomplicated access to legal abortion tend to be found in areas of the world, such as Europe and North America, with noticeably slower rates of population growth than those areas that place greater restrictions on women's access to abortion, such as Africa and Latin America. The proportion of women currently having uncomplicated access to legal abortion will continue to decline unless more countries, especially more populous countries, begin permitting abortion for economic or social reasons.

Figures 3 and 4 document variation in uncomplicated access to legal abortion by region. The most significant feature is that, whether using a country measure (Figure 3) or a percent of population measure (Figure 4), restricted access to legal abortion is most notable in the 52 African countries and the 30 Latin American/Caribbean countries. Women in these regions have also experienced the least change in their access to legal abortion over the last decade. As shown in Figure 4, as of 2007 only 2 percent of Latin American/Caribbean women have uncomplicated access to legal abortion, a slightly smaller fraction than in 1996. This decline is occurring even though by 2007 Saint Vincent and the Grenadines joined the four other countries in this region (Barbados, Belize, Cuba, and Guyana) that allowed uncomplicated access to abortion in 1996; the population living under more restrictive abortion policies is growing more rapidly than the population in these five countries. A similar pattern is evident for Africa, where only 7 percent of women have uncomplicated access to legal abortion in 2007 compared to 8 percent in 1996, even though the same four out of 52 countries permitted uncomplicated access in both time periods: South Africa, Cape Verde, Tunisia, and Zambia. For Europe and North America a very high percentage of countries permit uncomplicated access to abortion, and a very high percentage of women have uncomplicated access to abortion. In 2007 just four countries in these regions did not permit abortion for economic or social reasons: Ireland, Malta, Poland, and Spain. In Asia even though a minority of countries (40 percent) grant women uncomplicated access to abortion, a substantial majority of Asian women (73 percent) have uncomplicated access. This is so because China, with a 20 percent share of the world's population in 2007, and India, with an 
FIGURE 3 Percent of countries in each world region permitting abortion on request or for economic or social reasons, 1996 and 2007

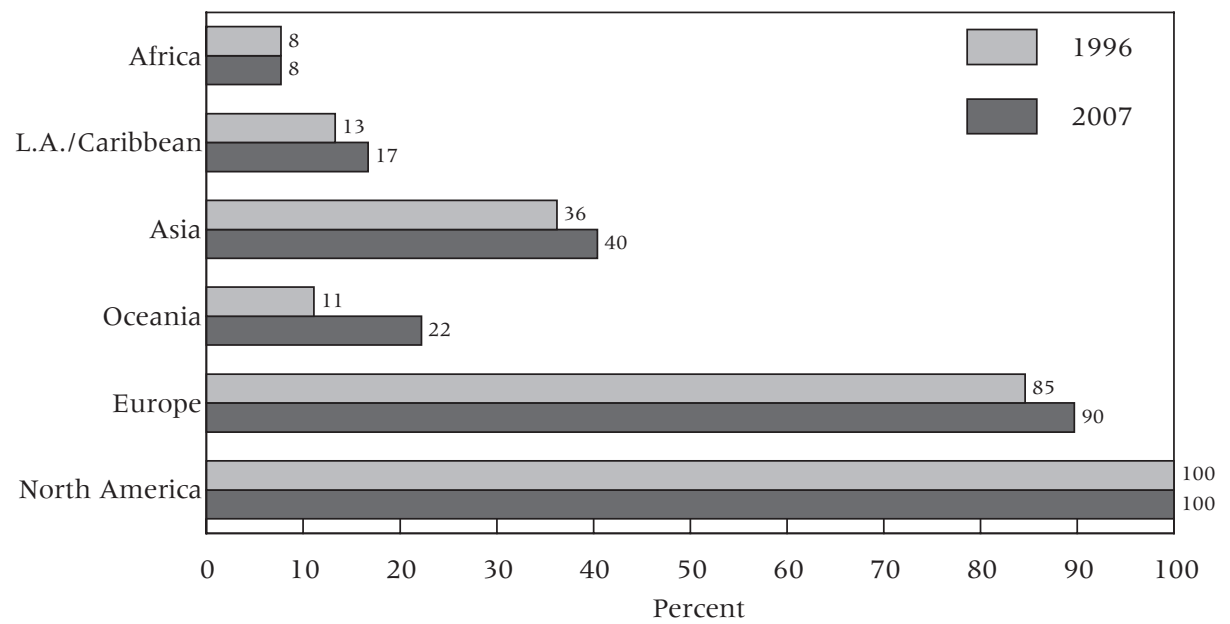

SOURCE: See Figure 1.

18 percent share, both have liberal abortion policies and together constitute 62 percent of the population residing in the 47 Asian countries. Only about 29 percent of women in the 45 other Asian countries had uncomplicated access to abortion in 2007. Oceania's contrasting statistics in Figures 3 and

FIGURE 4 Percent of population in each world region living in countries permitting abortion on request or for economic or social reasons, 1996 and 2007

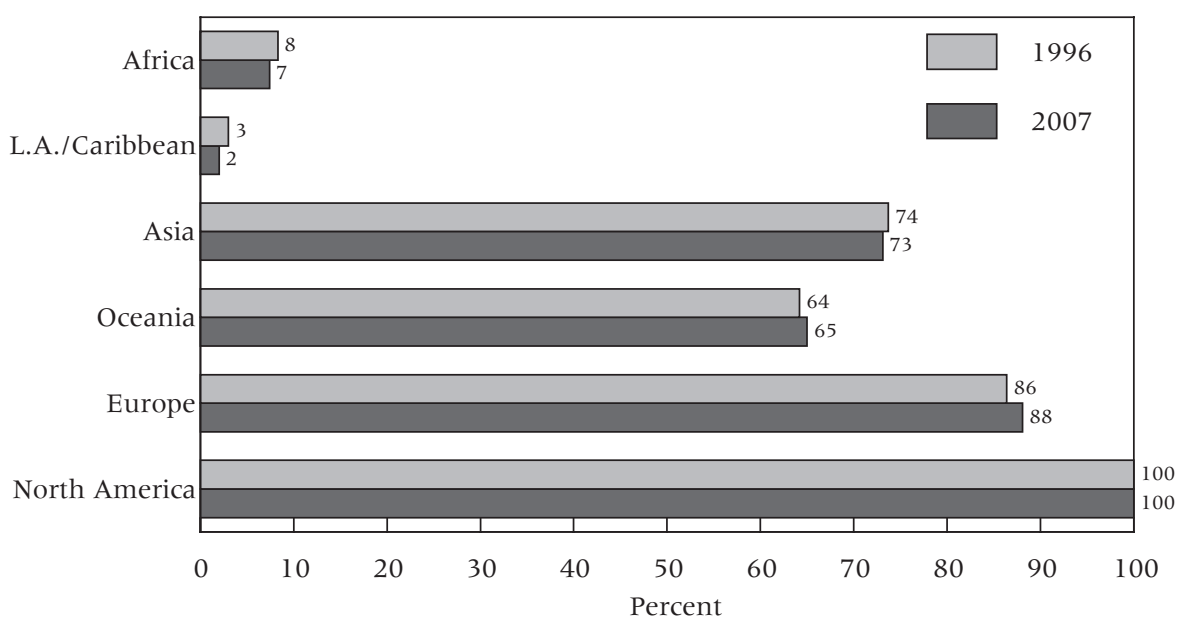

SOURCE: See Figure 1. 
FIGURE 5 Percent of countries in each development category permitting abortion on request or for economic or social reasons, 1996 and 2007

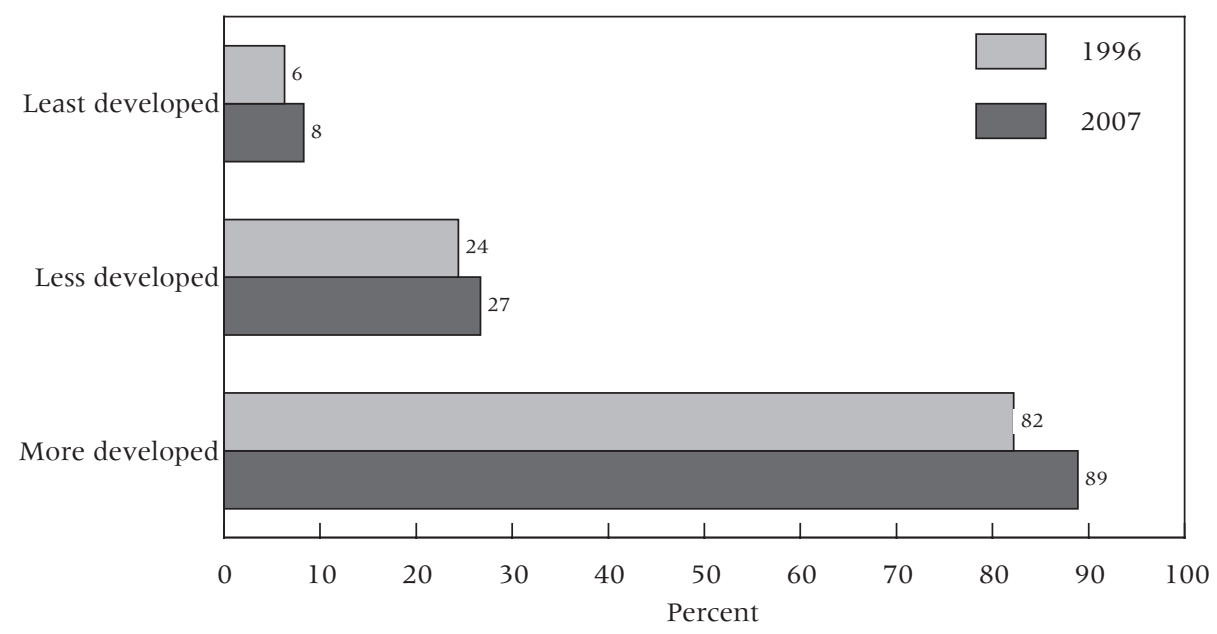

SOURCE: See Figure 1.

4 can largely be explained by Australia having a liberal abortion policy and constituting over 60 percent of that region's population.

Figure 5 documents a clear relationship between a country's development level and its abortion policy. Only four of the 48 countries classified as least developed in 2007 ( 8 percent) permit women uncomplicated access to

FIGURE 6 Percent of the population in each development category living in countries permitting abortion on request or for economic or social reasons, 1996 and 2007

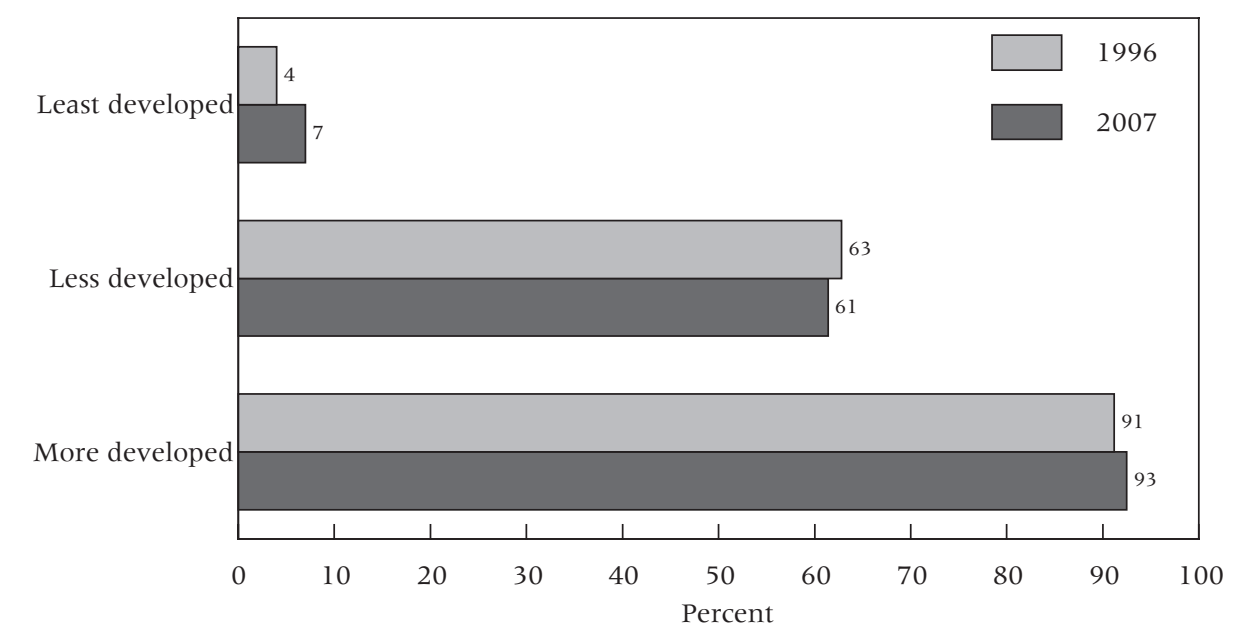

SOURCE: See Figure 1. 
abortion: Cambodia, Cape Verde, Nepal, and Zambia. This compares to 23 of the 86 countries classified as less developed ( 27 percent) and 40 of the 45 countries classified as more developed ( 89 percent). Figure 6 documents that women in the least developed world had much more limited access to uncomplicated legal abortion in 2007 (7 percent) than women in the more developed world (93 percent). Women's relatively high access to uncomplicated abortion in the less developed world (61 percent) needs further analysis. This high percentage is largely the result of the fact that both China and India, with their huge populations and liberal abortion policies, are classified as less developed; together they constitute 55 percent of the population residing in all 86 less developed countries. Only about 16 percent of women in the 84 other less developed countries had uncomplicated access to abortion in 2007, a percentage more similar to that of women in the least developed world than of women in the more developed world. In 2007 the population of women in the least developed world with uncomplicated access to abortion had a lower annual population growth rate (1.9 percent vs. 2.4 percent) and a lower total fertility rate ( 3.7 vs. 4.8 ) than women with more restricted access to abortion. The same situation holds true for women in the less developed world: women with uncomplicated access to abortion had a lower annual population growth rate (1.0 percent vs. 1.5 percent) and a lower total fertility rate (2.2 vs. 2.9) than women with more restricted access to abortion. Clearly, the populations in these two development categories with more restrictive abortion laws are at earlier stages of their fertility transitions.

This clear association between restricted access to legal abortion, lower levels of development, higher rates of population growth, and higher total fertility rates presents a challenge for those who wish to formulate population and reproductive health policies that serve the health needs of women. From what we know about the role induced abortion normally plays in fertility transitions, women in populations that are in the early and middle stages of their fertility transitions are most likely to experience increasing numbers of unwanted pregnancies and increasing numbers of induced abortions.

During periods of rapid decline in desired family size, common to the early and middle stages of the fertility transition, the potential for unintended pregnancies increases significantly as women desire to be pregnant for smaller and smaller portions of their reproductive years (Bongaarts and Westoff 2000: 194; Sedgh et al. 2007b: 113-114). Countries in the early and middle stages of their fertility transition commonly have simultaneous increases in use of both contraception and induced abortion since women rely on both to keep their actual fertility in line with rapidly declining desired fertility. That current abortion policies tend to be most restrictive in developing-country populations in the early to middle stages of their fertility transition has meant that the vast majority of abortions in such populations are illegal and therefore much less safe. 
This health problem exists because prohibiting abortion simply to end unwanted pregnancies has not prevented women from using abortion for this purpose. In 2003 in Africa 98 percent of all abortions were illegal, and these 5.5 million illegal abortions ended 12 percent of all pregnancies. In Latin America and the Caribbean 95 percent of abortions in 2003 were illegal, and these 3.9 million abortions ended 21 percent of all pregnancies (Sedgh et al. 2007a: 1342). Evidence suggests that a woman who is pregnant and does not want to give birth will strive to accomplish her goal regardless of legal barriers. But abortion restrictions do have an impact. Their most significant effect is on the health of women who obtain abortions. The World Health Organization estimates that in Africa in 2003 the case-fatality rate (deaths per 100,000 abortion procedures) was 650 for women receiving illegal abortions, and in Latin America and the Caribbean it was 50. This compares with a case-fatality rate of 0.6 for legal abortions performed in the United States (WHO 2007: 18). An estimated 65,000 to 70,000 women die each year as a result of complications from unsafe abortions, 5 million suffer a period of disability, 3 million experience reproductive tract infections, and 1.7 million experience secondary infertility (WHO 2007: 5). Restricted access to abortion also results in more unwanted pregnancies coming to term than would be the case if abortion were more freely available. Where access to legal abortion is uncomplicated, the vast majority of women who attempt to end an unwanted pregnancy usually succeed, even in developing countries. For example in Mongolia, where abortion is freely available, the 1998 Reproductive Health Survey reported that only 2 to 3 percent of women attempting to end an unwanted pregnancy failed to do so. In most cases significantly higher proportions of women fail to end unwanted pregnancies where access to legal abortion is more highly restricted (WHO 2007: 4).

That demand for abortion tends to increase during the early and middle stages of fertility transitions should be an important consideration for those formulating population policies. Countries in those stages of their fertility transition are the most likely to adopt policies to lower their fertility, ones aimed at fostering small-family norms and stimulating rapid declines in desired family size. The 2007 total fertility rate of the population living in countries with a policy to lower fertility (those I refer to here as antinatalist countries) is 3.3, compared to a TFR of 2.7 for the population living in countries with a fertility policy of no intervention, a TFR of 1.9 for the population living in countries with a policy to maintain fertility, and a TFR of 1.4 for the population living in countries with a policy to raise fertility. Currently 47 percent of the world's population live in countries with a policy to lower fertility, a statistic that does not include China's 20 percent of the world's population. China's official 2007 policy is to maintain, not lower, its current fertility rate, given by the UN as 1.7. Two-thirds of the 72 countries with a policy to lower fertility are African and Latin American/Caribbean countries, 94 percent of which restrict access to legal abortion. None of the ten antinatalist countries 
in Latin America and the Caribbean ${ }^{3}$ and only three of the 38 antinatalist countries in Africa $^{4}$ permit abortion on request or for economic or social reasons. These countries have encoded in their legal systems the admonition that abortion should not be viewed as a means of family planning. Although they have adopted policies to induce more women to have smaller families, they have made it illegal to end a pregnancy simply because it is unwanted. This combination of population and abortion policies is a clear contraceptiononly fertility control policy; even when contraceptive failure is the cause of a pregnancy, as happens to an estimated 26 million women annually (WHO 2003: 13), abortion is not permitted.

When policymakers from these countries turn to Program of Action documents adopted at international conferences on population, even the recent Cairo+5 and Cairo+10 documents (UN 1999: 625; UNFPA 2005: $80-81$ ), they find no discussion of the relationship between likely numbers of abortions and stage of the fertility transition. They simply find the common-ground directives that "...in no case should [abortion] be promoted as a method of family planning," and that it is possible "to reduce the recourse to abortion through expanded and improved family-planning services." Yet the best evidence indicates that reality is more complicated than the directives suggest. A dynamic relationship exists between contraceptive prevalence rates and abortion. Both tend to increase in the early and middle stages of the fertility transition. An inverse relationship can only be expected to develop in the later stages of the fertility transition when sterilization commonly is used to end childbearing and when child spacing is accomplished by well over half of reproductive-age women using highly effective modern means of contraception. Countries initially instituting effective antinatalist policies that induce couples to want smaller families, even if they facilitate access to contraception, can expect the number of induced abortions to increase along with contraceptive use. With desired family size declining rapidly, women have a new and urgent need for contraception but often must overcome cultural barriers to its use, take time to find out where to obtain it, and learn how to use it correctly. During this period, unintended pregnancies are likely to increase in number and unwantedness. Often there is a simultaneous increase in the age at marriage, and women face more years during which they are unmarried and sexually active. Unmarried sexually active women face additional barriers to gaining access to contraception and additional reasons for wanting to end unintended pregnancies. It is predictable, therefore, that more women will seek abortions when desired family size is declining rapidly. Considering their stage in the fertility transition, it is not unexpected that 600,000 more African women sought abortions in 2003 than in 1995 (Sedgh et al. 2007a: 1341).

The common-ground directive that "in no case should [abortion] be promoted as a method of family planning" makes it difficult to present evidence at international population conferences that uncomplicated access to legal 
abortion actually allows women in countries attempting to spread a smallfamily norm to accomplish their new reproductive goals in a more healthful manner. Table 1, for instance, suggests that demonstrable demographic and health benefits are associated with antinatalist policies that are in place in countries where women have uncomplicated access to legal abortion. Except for the "number of countries" and "percent of countries" data, all measures in Table 1 are "percent of population" measures. ${ }^{5}$

Note that the 43 percent of the population in antinatalist countries with uncomplicated access to abortion has a 28 percent lower per capita income $(\$ 2,426)$ than the 57 percent of the corresponding population with more restricted access to abortion $(\$ 3,363)$. This marked difference in development level makes the following statistics all the more remarkable. The population with uncomplicated access has a 22 percent lower total fertility rate ( 2.8 vs. 3.6) and a 21 percent lower total annual rate of population growth (1.5 per-

TABLE 1 Cross-tabulation of demographic and health measures of populations living in countries with a policy to lower fertility, according to whether or not countries permit abortion on request or for economic or social reasons, 2007

\begin{tabular}{|c|c|c|c|}
\hline & \multicolumn{2}{|c|}{$\begin{array}{l}\text { Abortion permitted on } \\
\text { request or for economic } \\
\text { or social reasons }\end{array}$} & \multirow[b]{2}{*}{ Total } \\
\hline & Yes & No & \\
\hline Number of countries & 10 & 62 & 72 \\
\hline Percent of countries & 14 & 86 & 100 \\
\hline Percent of population in antinatalist countries & 43 & 57 & 100 \\
\hline Percent of world's population & 20 & 27 & 47 \\
\hline Population growth rate & 1.5 & 1.9 & 1.7 \\
\hline Total fertility rate & 2.8 & 3.6 & 3.3 \\
\hline Female life expectancy & 66.5 & 64.7 & 65.5 \\
\hline Infant mortality rate (per 1000 births) & 53 & 55 & 54 \\
\hline Under-5 mortality rate (per 1000 births) & 75 & 83 & 80 \\
\hline Maternal mortality ratio (per 100,000 births) & 438 & $502^{c}$ & 475 \\
\hline Percent using modern contraception ${ }^{a}$ & $49^{d}$ & $37^{\mathrm{e}}$ & 42 \\
\hline Percent using any contraception ${ }^{a}$ & $57^{\mathrm{d}}$ & $44^{\mathrm{e}}$ & 50 \\
\hline GNI per capita, ppp $2006^{\mathrm{b}}$ & $\$ 2,426^{\mathrm{f}}$ & $\$ 3,363^{\mathrm{g}}$ & $\$ 2,958$ \\
\hline
\end{tabular}

${ }^{a}$ Reproductive-age women: World Contraceptive Use 2007, United Nations, Department of Economic and Social Affairs, Population Division; «http://www.un.org/esa/population/publications/contraceptive2007/contraceptive2007.htm"

${ }^{\mathrm{b}}$ Gross national income per capita, ppp (current international \$), 2006 data from World Bank, World Development Indicators database; "http://devdata.worldbank.org/data-query/»

${ }^{c}$ data missing for .03 percent of the population (Micronesia, Samoa, Vanuatu)

${ }^{\mathrm{d}}$ data missing for .063 percent of the population (Fiji)

${ }^{\mathrm{e}}$ data missing for .058 percent of the population (Micronesia, Samoa, Solomon Islands, Vanuatu)

${ }^{\mathrm{f}}$ data missing for .057 percent of the population (Bahrain)

${ }^{g}$ data missing for 1.11 percent of the population (Congo, Oman, Zimbabwe)

SOURCE: See Figure 1. 
cent vs. 1.9 percent). The higher total fertility rate of the antinatalist population with more restricted access to legal abortion indicates that it is in the earlier stages of its fertility transition, when increasing numbers of women are likely to find themselves with unwanted pregnancies. Although accurate estimates of illegal abortion are not available at the country level, the population living under more restrictive abortion policies has a 15 percent higher maternal mortality ratio than the population with uncomplicated access (502 versus 438 deaths per 100,000 live births), suggesting that significant numbers of women in this population might be resorting to harmful illegal abortions. In fact, even with a significantly lower per capita income, all the mortality measures of the population with uncomplicated access are superior to those of the population with restricted access: a 4 percent lower infant mortality rate, a 10 percent lower under- 5 mortality rate, and a 3 percent higher female life expectancy. Additionally, the population with uncomplicated access has a 30 percent higher use rate of "any contraception" and a 32 percent higher use rate of "modern contraception" than the population with restricted access. There is no evidence that easier access to legal abortion is causing women to forgo practicing contraception or that restricting access to legal abortion is causing women to seek out contraception in greater numbers. Evidence suggests that women in antinatalist countries that restrict access to abortion have lower contraceptive use rates, poorer health conditions, and higher fertility than women living in antinatalist countries with uncomplicated abortion access, and that these differences cannot be explained by economic factors.

The current common-ground approach to abortion adopted at international population conferences inhibits forthright discussion of the interplay of abortion, contraception, and population policy. The directive that all governments should "reduce the recourse to abortion through expanded and improved family-planning services" might be politically useful, but it makes it difficult to talk about those stages of fertility transition when contraceptive use and abortion can be expected to increase together. The directive meant to rally support for expanding access to contraception- “abortion should never be used as a means of family planning"-makes it inconvenient to acknowledge that millions of women currently are doing just that, or that some countries allowing such a use are probably experiencing health and demographic benefits as a result. It is easy to understand the political reasons why such topics have been avoided at international population conferences, especially when the avoidance was reinforced by provisions of the Mexico City Policy of the United States, but maintaining silence on these topics has always had its costs. Even policymakers who view abortion as an act of taking a human life, and who are not likely to change the highly restrictive abortion policies that flow from that moral position, have something to gain from open forums that disseminate the best information available on the likely consequences of particular abortion and population policies. Discussion of the health costs as- 
sociated with undergoing a fertility transition with restrictive abortion policies will allow even these policymakers to better plan for the increase in unsafe abortions they are likely to experience. Avoiding these topics probably has never served the best interests of policymakers, but continuing to contain all discussions of abortion, family planning, and population policy within the confines of these two common-ground directives is becoming increasingly untenable. Too many facts simply cannot be made to conform to them.

Considering the highly charged politics that surrounds the issue of abortion at both the national and international levels, a debate over whether a new common-ground approach is needed is likely to be controversial, and perhaps as contentious as any debate over what that new approach ought to entail. Tracing how the contraception-only definition of family planning became de rigueur at international population conferences is a useful first step in determining whether the present is an auspicious time to revisit past compromises. Such a history might also help to identify some components of a new common-ground approach.

\section{The origins of a contraception-only population policy}

Induced abortion has always been a significant factor affecting numbers of births and population growth rates (Himes 1932: 49; Davis and Blake 1956: 229-230; Frejka 1985: 230). Historically, women have used abortion to deal with a personal problem that the state often ignored and occasionally penalized. In the twentieth century when states began to formulate explicit population policies, the demographic significance of abortion made it more difficult for the state to ignore. When populations faced stagnant growth or the prospect of actual population decline, concerned policymakers often saw abortion as a harmful act for both society and the individual. Occasionally laws outlawing abortion were combined with ones that barred the use of contraceptives to form a coercive pronatalist policy. When populations experienced rapid growth, policymakers concerned about resource shortages, unemployment, and economic stagnation often saw abortion as a health-promoting act for both society and the individual, and worked to make abortion, along with contraception, more readily available to women as part of a comprehensive antinatalist policy. In short, during the twentieth century at the national level, abortion policy became a potentially powerful means to accomplish a variety of population policy ends, and policymakers' willingness to use it as such has caused them to see abortion in different lights. Late in the twentieth century reproductive rights movements in many countries attempted to refocus discussions of fertility control at the level of individual women. From a reproductive rights perspective, control of fertility is an individual woman's right that never should be overruled in pursuit of state interests. 
A contraception-only antinatalist population policy was first promoted by the international population control movement that arose in certain modern industrialized countries after World War II. Rapid mortality decline in the developing world was causing very rapid population growth. Movement leaders thought that such growth threatened the economic and political wellbeing of less developed countries and sought to convince both developed- and developing-world governments to support family planning programs in these still predominantly agrarian societies. By the early 1960s family planning came to be defined in exclusively contraception-only terms and as a program that could not only reduce population growth but could reduce illegal abortion as well. The decision to define family planning as contraception only and anti-abortion was deliberate and, no doubt, seemed the prudent decision to make at the time. Movement leaders were familiar with several national integrated abortion and population policies then in place: France's coercive pronatalist policy that included restriction of access to both contraception and abortion in an attempt to produce larger families; and Japan's antinatalist policy adopted in the period immediately after World War II that included the decriminalization of contraception and abortion in an explicit attempt to lower a problematically high rate of population growth. A brief digression to examine these two national integrated programs is useful for two reasons. First, it reveals the thinking of two sets of policymakers who viewed abortion quite differently. With contemporary international population policy discussions increasingly having both an antinatalist and a pronatalist dimension, such an expansive understanding of policymakers' perspectives on abortion is important. Second, it gives insight into how movement leaders during the 1950s and 1960s used what was known about abortion and population policy when fashioning their initial antinatalist policy recommendations. When reviewing this history it is important to remember that it occurred in a policy environment in which women's voices were largely unheard.

\section{French pronatalism}

Early in the twentieth century, France had an active birth control movement, the production and sale of contraceptives were legal, and French fertility, in decline for about a century, was low (Accampo 2003). After the devastating military loses suffered in World War I, however, France's persistent worry over the prospect of depopulation turned to despair. In 1920 the French government, advised and aided by French population experts, enacted a strongly pronatalist population policy that sought to encourage fertility through a combination of positive programs that enhanced couples' ability to care for children (Watson 1954) and repressive programs that limited couples' access to contraception and abortion (Watson 1952). My focus is on the repressive programs because they explicitly linked abortion policy and population policy. 
The law of 13 February 1920 made manufacturing, selling, or advocating the use of contraceptives illegal, punishable by fines or imprisonment. The French birth control movement found itself under systematic attack and with little public support. Abortion before that time was illegal, with harsh penalties specified, but few juries convicted abortion providers and abortions were frequent. Amendments to Article 317 of the Penal Code, the article that made abortion illegal, were enacted in 1923 to rectify that situation. The 1923 amendments eliminated jury trials for abortion cases and set jail terms for women obtaining abortions at six months to two years and for abortion providers at one to five years. Physicians performing abortions could also be permanently barred from practicing medicine. Convictions increased, although even under the new amendments obtaining evidence was still difficult. Fewer medical personnel performed abortions under the new laws but abortions remained common, estimates ranging from 300,000 to 500,000 a year during the 1930s (Watson 1952: 265), a decade when the average annual number of live births was 671,000 (INEE 2009). The estimated abortion ratio, then, was somewhere between 450 and 750 abortions per 1,000 live births.

At the end of the 1930s the Comité consultatif de la population was appointed to strengthen France's coercive pronatalist population policy. It produced the Code de la famille in July 1939, shortly before France entered World War II. Its new laws were largely implemented by the government of Marshal Pétain. Under the Code de la famille, abortion was viewed as an anti-state act. Greater restrictions were to come. The law of 15 February 1942 made abortion a crime against the state, comparable to sabotage and treason. As an "act against the material security of the State," abortion cases were tried by a special Tribunal d'état whose decisions were final and whose penalties were to be imposed immediately (Watson 1952: 267). In July 1943 the Tribunal d'état had a Cherbourg laundress, Marie-Louise Giraud, put to death by guillotine for performing 26 abortions (Koos 1999: 21). It sentenced the three women who solicited customers for her to from five to ten years of forced labor.

Still, abortions remained frequent. Debré and Sauvy (1946: 183) estimated that between 400,000 and 500,000 abortions were performed in 1946, a year in which there were 844,000 live births in France (INEE 2009). The estimated abortion ratio was between 470 and 590 abortions per 1,000 live births. The Code de la famille remained in effect after the war, and French population experts undertook studies aimed at identifying who was having abortions and why. Jean Sutter (1950) of INED (l'Institut national d'études démographiques) interviewed 3,000 women arriving at hospitals with post-abortion complications from 1946 to 1949 and found that the average "abortee is a married woman with a small family" and that "the family appears to be a quite normal one" (Watson 1952: 275). These findings did not convince population experts that normal French wives needed access to modern contraception and legal abortions so as to be spared the health consequences 
of repeated illegal abortions performed by ill-trained providers. The experts actually arrived at the opposite conclusion: restrictions on contraception needed to be maintained and the penalties for abortions strengthened. Clearly, few women's voices were being heard, perhaps because women had only gained the right to vote in France in 1944 (Latham 2002: 17). The state's pronatalist population policy was the preeminent concern of policymakers, and they viewed suppressing abortion to be a necessary component of that policy. Alfred Sauvy (1945: 297; Watson 1952: 285), then director of INED, was clear about this: "the repression of abortion, although it cannot be used alone, is according to German and Austrian experience the most effective and least onerous means of affecting natality."

The perception that the state needed more people produced a highly articulated population and abortion policy. State needs, not individual desires, were of paramount importance. Jean Sutter implored couples to give their families "a size which finally will be in accord with the needs of the nation" (Watson 1952: 283). Paul Vincent, also of INED, classified "La famille normale" as one with three or four children, and argued that a large family, even if "for the most part involuntary," was needed for France's "demographic equilibrium" (1950: 266-268; Watson 1952: 285).

Not until 1967 was there a statutory provision for the legal distribution of contraceptive devices in France (Latham 2002: 53). By that time worries over depopulation had dissipated since France's total fertility rate had been in the range of 2.6 to 2.8 for over 20 years. Women had also begun to mobilize and press for greater access to contraception. Dr. Marie-Andreé Weill-Hallé established her family planning association in 1956, and it quickly became a woman-focused national family planning association, Mouvement français pour le planning familial, which started distributing contraceptives to women despite the restrictive law. During his 1965 presidential campaign François Mitterrand included ending birth control restrictions as part of his platform (Latham 2002: 57-59, 71) and by 1967 the restrictions were gone. A law passed in January 1975, loi Veil, suspended Article 317 of the Penal Code under certain circumstances. Pregnant French women in situations of "distress" could now obtain legal abortions during the first trimester of their pregnancies (Latham 2002: 94). ${ }^{6}$ France's experiment with coercive pronatalist policies ended that year. In 2003 there were some 208,000 abortions in France (Sedgh et al. 2007b: 108) and 761,464 live births (INEE 2009) for a ratio of 273 abortions per 1,000 live births, a considerably lower ratio than those estimated for the decades when nearly all abortions were illegal. ${ }^{7}$

\section{Japanese antinatalism}

Japanese fertility was declining in the early decades of the twentieth century (Whelpton 1950: 34). During the 1920s contraceptives were legally sold in 
Japan, and information about contraception was widely distributed. Although initially rebuffed by officials, Margaret Sanger received approval by the Imperial Diet to speak publicly on birth control during her 1922 tour (Gray 1979: 185-188), a tour that served as a launching pad for the Japanese birth control movement led by Shidzue Ishimoto (Chesler 1992: 246; 365-367). But during the 1930s Japan's new militarist leaders wished to encourage population growth. They made a concerted effort to stop the spread of birth control information and used the police to prevent the sale of contraceptives (Dore 1953: 82-83; Oakley 1978: 620-622). After Sanger's second visit to Japan in 1937, Ishimoto was jailed for promoting "dangerous thoughts," and her movement was outlawed (Chesler 1992: 367). The crude birth rate rebounded a bit from 1940 to 1941, but declined during the war years, reaching a low of 23.2 in 1945.

With the war's end, however, the crude birth rate rose sharply to 34.6 in 1946, and stayed at that high level through 1949. These four years of rapid natural increase added about 8 million people to Japan's population, which reached 83 million by 1949. In a country stripped of its former colonies, with soldiers and repatriates returning from abroad, and with its industrial base severely shattered by massive bombing, Japanese leaders feared that their future would be threatened by severe overpopulation. In 1948 the Japanese Diet passed two laws that formed the core of a comprehensive antinatalist policy (Norgren 2001). The Pharmaceutical Affairs Law repealed all laws restricting the sale and marketing of contraceptives. The Eugenic Protection Law legalized abortion and sterilization for the protection of the mother's health. In 1949 the latter law was amended to allow abortions on grounds of economic hardship (ibid.: 36-46). Both contraception and abortion were approved as subsidized services covered by the national health plan.

The government took a clear antinatalist stance and the Supreme Command Allied Powers-the US occupation force-largely concurred with its assessment (Oakley 1978). In April 1949 Prime Minister Yoshida stated that "it was necessary for the people themselves fully to understand and practice the principles of birth control in order to surmount the stringent economic times" (Whelpton 1950: 40). On the same day a Population Problem Council was established in the Cabinet. In October 1949 the Council recommended to the Prime Minister that every couple should be "enabled" to control their family size "in order to prevent a tremendous increase of population which will influence disadvantageously the economic rehabilitation." It also argued that "special efforts must be made toward enlightenment of the social class in which the dissemination and practice of birth control are most difficult" (ibid.: 41).

The passage of these laws had its desired effect. A month after the Pharmaceutical Affairs Law was passed a variety of contraceptives was approved for sale, and within a year contraceptive production had greatly increased 
(Whelpton 1950: 38-39). The Population Problems Research Council, established by the Mainichi Newspapers in 1949, undertook three national surveys from 1950 to 1955 and found that the proportion of couples using contraception had increased from 29 percent to 52 percent (Taeuber 1956: 28). During the same period abortions rose in an even more dramatic fashion: 246,000 in $1949 ; 489,000$ in $1950 ; 638,000$ in $1951 ; 798,000$ in $1952 ; 1,068,000$ in 1953; and 1,143,000 in 1954 (ibid.: 27). For the remainder of the 1950s abortions held at the level of 1.1 million a year (Balfour 1961: 104), and by 1959 the abortion ratio was 676 abortions per 1,000 live births (Davis 1963: 347). That the majority of Japanese women could receive a high-quality abortion at a cost of less than one US dollar (Taeuber 1956: 30) no doubt helped fuel this increase. Japan's total fertility rate fell from 4.4 in 1948 to 2.0 by 1957, and remained at replacement level until 1973 (United Nations 2000). Government leaders, national population experts, and a committed medical establishment directed Japan's antinatalist policy; family planning associations and general women's organizations played minor roles (Norgren 2001: 36-52). During the 1950s Japan's rapid fertility decline was heralded, both inside and outside the country, as a great success.

After 1973 Japanese fertility resumed its decline, falling to 1.3 in 2006. Through much of this period Japanese women relied on condoms as their major means of contraception since the pill was not approved for contraceptive use until 1999 (Kihara et al. 2001). By the early 1980s, when the declining TFR reached 1.7, some Japanese began to assert that restrictions on abortion were needed. In 1982 the Seichō no Ie, a religious organization with ties to nationalists and conservative Diet members, launched a "Reverence for Life" movement and sought to gather 10 million signatures for the repeal of the economic hardship clause of the Eugenic Protection Law. A coalition of women's groups, trade unionists, physicians, and female members of the Diet, however, succeeded in preventing this radical change in the abortion law. Throughout the 1980s government actions indicated it was abandoning its antinatalist policy for a pronatalist one (Gelb 1996: 129-130). Some actions indicated a willingness to adopt very heavy-handed pronatalist policies: delaying approval of the pill for contraceptive use even though by 1991 it had been proven to be safe and effective in government trials, and attempting to shorten the period of uncomplicated access to abortion from 23 weeks of pregnancy to 21 weeks. By the early 1990s more progressive pronatalist policies were enacted, including significantly increasing monthly child support payments, granting either parent a one-year unpaid leave for child care after the birth of a child, and providing a variety of help for those wishing to combine childrearing and paid work (Ogawa 2003: 102-103). In 2003 there were an estimated 320,000 abortions in Japan and 1,134,000 live births (Sedgh et al. 2007b: 110) for an abortion ratio of 282 abortions per 1,000 live births, a considerably lower ratio than for the peak abortion years of the 1950s. 


\section{Abortion and the international population control movement}

The French and Japanese examples of an integrated abortion and population policy were current when the international population control movement began its attempt to halt the developing world's rapid population growth during the 1950s and 1960s. This growth was especially problematic when viewed through the lens of demographic transition theory then being developed by demographers at Princeton University's Office of Population Research (Hodgson 1983). If rapid population growth prevented the transformation of traditional agrarian societies into modern industrial ones, then rapid population growth might forestall the very socioeconomic changes that would induce fertility decline. Without fertility decline, the developing world's period of population expansion would come to an end with mortality rising as starvation and disease increased, changes likely to create political and economic chaos.

Princeton demographers broadcast this vision of the postwar global population situation, and by the early 1950s John D. Rockefeller 3rd and eventually the leadership of the Ford and Rockefeller Foundations had accepted its validity. They launched a movement with a global focus. A 1962 policy paper of the Board of Trustees of the Ford Foundation (Harkavy 1995: 39) stated publicly their intent "to achieve breakthroughs on the problems of population control, including training and research in demography, the motivational factors in family planning, the political and social consequences of population control, and the pertinent areas of science, medicine and public health." A year later the Rockefeller Foundation's Population Program was so bold as to list its goal as "the development of the knowledge and experience needed to bring about reduction of the growth rate of the world's population and its eventual stabilization," a goal that Harkavy (ibid.: 44) argued "could have served equally well for the Ford Foundation and the Population Council." They hoped to lower fertility by setting up family planning programs that would promote the small-family norm and distribute contraceptives. Movement leaders recognized that only governments could implement effective family planning programs, and the leaders' immediate task in the 1950s and early 1960s became to convince policymakers, in both developed and developing countries, that high fertility was a major social problem requiring state intervention.

India officially launched a small state-sponsored family planning program in 1952 and sought help in 1954 from the Population Council, the think tank of the movement, but interest was lacking in much of the rest of the developing world. Movement leaders needed to convince a skeptical and diverse set of national policymakers about the possibility and desirability of controlling fertility. The Cold War fears of many American and Western 
European leaders made them susceptible to arguments about the possible destabilizing effects of rapid population growth in the developing world, and a universal desire for economic development made developing-world leaders susceptible to the appeal of models, such as that of Coale and Hoover (1958), quantifying the economic gains that would accrue from lowering fertility. Still, many policymakers in less densely settled regions of the world, especially in Latin America and Africa, were convinced that more people, not fewer, would help their development.

Through much of the 1950s and early 1960s simply getting government leaders to publicly declare support for family planning was difficult. At the United Nations World Population Conference held in Rome in 1954, a coalition of Catholics and Communists prevented consideration of any fertility control agenda. In 1959 President Dwight Eisenhower forcefully ruled out any use of US foreign aid funds to support birth control in developing countries, describing it as "not a proper political or governmental activity or function or responsibility" (Morris 1959: 1).

The international population control movement did have an ally in the effort, although one that was small and poorly funded. In 1946 Margaret Sanger came out of retirement in an effort to internationalize the Planned Parenthood movement that she had initiated in the United States decades earlier (Chesler 1992: 407-463). She was chair of the committee that formally established the International Planned Parenthood Federation in Bombay, India, in 1952 and she co-directed the IPPF until her retirement in 1959. She imprinted it with her feminist belief that birth control was essential for women's equality. IPPF representatives and members of the Population Council met in 1955, 1956, and 1957 "to develop and define general principles for promoting birth control overseas" (Piotrow 1973: 14). When significant funds for global fertility control began to flow from foundations, however, they were largely funneled not to the IPPF birth controllers but to movement operatives (ibid.: 15-18). These operatives viewed the IPPF's moderate feminist rationale for family planning as a valuable supplement to their economic and political arguments for fertility control. Personally they feared that the traditional male-dominated social structures of agrarian societies were organized in ways that induced high fertility, yet they harbored hopes that Sanger was correct in her belief that all women desired to control their fertility but simply lacked the means to do so. The IPPF's "planned parenthood" model focused on providing contraceptives to women and did not include advocacy of abortion. In fact the IPPF, like Sanger's earlier domestic birth control movement, promoted family planning as an alternative to (mostly illegal) abortion.

In the policy environment of the 1950s and 1960s any promotion of abortion by the international population control movement would have greatly complicated its political agenda. Abortion for birth control purposes had yet to be legalized in any Western industrialized country, and most such 
countries had abortion laws similar to those in place in France. Yet Japan's success in halving its fertility rate in less than a decade seemed to provide the ideal blueprint for reining in population growth. Some experts discounted the applicability of the Japanese example, pointing to the country's long tradition of using abortion and infanticide to control fertility (Taeuber 1958: 29-31), but others disagreed. Kingsley Davis argued (1963: 345-346) that the Japanese abortion experience had been "the same in kind as the behavior of West Europeans at a similar time in their social and demographic history," differing only in that "Japanese tolerance permits the abortion rate to be reasonably well known." He found that the past prevalence of abortion in Western European countries and the current prevalence of abortion in the People's Republics of Eastern Europe were "amazingly like that of Japan," and that "there is no reason to regard the resort to abortion as peculiarly Japanese." For Davis a high abortion rate is simply "a response to social and economic conditions arising in country after country at a particular time in the process of modernization." Judith Blake, too, thought that Japanese openness held a lesson for others: "the Japanese were probably fortunate in not being overly burdened and confused in their family planning by institutionalized superstition and unreasoned fears concerning abortion" (1963: 323). But advocating a Japanese-style integrated antinatalist program threatened to generate significant opposition in many potential donor and recipient countries. In the end, movement leaders such as John D. Rockefeller 3rd made a concerted effort in the early 1960s to gain US government support for a simple voluntary family planning program that would distribute contraceptives to women who wanted them, arguing that such a program was a necessary complement to the gradualist development strategies being promoted by American foreign aid programs. In 1965 President Lyndon Johnson promised in his State of the Union Message "to help deal with the explosion in the world population" (Critchlow 2001: 71). By the end of the decade the US government had become the largest provider of funds for family planning programs in less developed countries.

Some developing-world political leaders needed additional persuasion of family planning's necessity, especially Latin American leaders whose strong Catholic beliefs predisposed them to oppose contraception. In this instance illegal abortion provided movement leaders with an effective argument in generating support for family planning programs that promoted contraceptive practice. With infant mortality rates falling, Latin American women found their family sizes rapidly expanding, and they were turning to illegal abortion in unprecedented numbers. Women with complications from unsanitary abortions were filling up hospital beds throughout Latin America. Movement leaders provided funds for surveys that measured the incidence of illegal abortion in Latin America and quantified its health effects and medical costs. A 1960 epidemiological study in Chile outlined the extent of the problem: "20 abortion complications were admitted for every 100 live births in hospitals, 
and...between 1938 and 1960 the number of abortion cases had more than tripled" (Stycos 1964: 371). These findings were used to persuade skeptical political leaders, largely "unconvinced of a population problem," that family planning programs were needed as anti-abortion programs:

Abortion complications were expensive and competing for overcrowded bed space and facilities. Interest in contraception increased: contraception would reduce abortion but not the birth rate-it was merely a substitute for abortion. While the rightists saw abortion as expensive, the leftists saw contraception as correcting class inequalities. Why should the upper classes have modern contraception and the lower classes abortion? A number of public hospitals quietly initiated contraceptive programs. (ibid.: 372)

This strategy proved successful, and by the late 1960s "implicitly or explicitly, all family planning programs in Latin America aim at fighting induced abortion as one of their principal objectives" (Requena 1968: 797). The strategy also helped to deal with Roman Catholic opposition since "the Church has not reacted aggressively" to family planning programs framed as anti-abortion programs (Stycos 1967: 76). In time some Latin American countries did come to believe that their chances for economic development were being threatened by high rates of population growth, most notably Colombia, Mexico, the Dominican Republic, and El Salvador (Measham 1975: 281).

The community studies undertaken in Latin America to determine the extent to which a family planning program could be an effective anti-abortion program produced surprising results. A family planning program introduced in Santiago, Chile led to a significant increase in the use of both contraception and abortion (Faundes-Latham et al. 1968: 844). Requena and Monreal explained their similar results by hypothesizing that "women who never before had thought of planning their family decided to do it, following advice from neighbors and drug stores. This means, probably, that a very large additional number of women used contraceptives in a wrong way and had undesirable pregnancies that ended in abortion" (1968: 202). Requena developed a class-based explanation of the interaction of abortion and contraception: the lower classes were using neither, the upper classes were effective users of contraception and only occasionally used abortion, and the middle classes were intensifying their use of both contraception and abortion (1970: 381). By the end of the 1970s the positive relationship between abortion and contraception during the early stages of the fertility transition was so widely known that Potts, Diggory, and Peel could summarize it succinctly: "Abortion is the horse that pulls contraceptive practice into the community" (1977: 498). They had accumulated significant "epidemiological evidence that the induced abortion rate rises in many (or possibly all) communities at the beginning of the demographic transition" (ibid.: 456). The Japanese experience of the 1950s was now seen to be the common one, as Davis had argued. 
These findings did not alter the decision of movement leaders to exclude advocacy of abortion. In the 1950s they were concerned about the high failure rate of the contraceptives then available, but they had given the Population Council significant funds to develop a contraceptive with the characteristics needed to lower developing-world birth rates: effective, inexpensive, not requiring repeated action, and unconnected to intercourse. The Council had rehabilitated an older method, the intrauterine device, and by the mid-1960s was manufacturing and distributing worldwide the Lippes Loop, a spiral, plastic IUD that could be inserted through a tube into a woman's undilated cervix by a medical technician (Connelly 2008: 201-206). The members of the international population control movement had what they hoped was an inexpensive and effective contraceptive method that could accomplish their goal. They thought that introducing abortion into the mix would only complicate matters. The United Nations already had defined "family planning" in exclusively contraceptive terms and presented it as a tool for combating illegal abortion (United Nations 1964: 30), and the movement's use of the same argument in Latin America had proven effective. Although Kingsley Davis called family planning "a euphemism for contraception" (1967: 731) and thought that "family planners" were "denying the central tenet of their own movement" by not advocating the legalization of abortion since "abortions enable women to have only the number of children they want" (ibid.: 733), the movement did not reconsider the matter. The mid-1960s was a period of some optimism for the movement as increasing numbers of government leaders were issuing public statements supporting family planning, and even Pope Paul VI was reassessing whether modern methods of contraception contravened Catholic doctrine.

By the end of the 1960s conditions had changed. The Pope had issued his encyclical, Humanae Vitae (1968), disapproving all methods of contraception, and reports of significant IUD infection rates and high removal rates were causing consternation in movement circles. In Taiwan only 25 percent of women had their original IUD in place 30 months after insertion, and more than 50 percent of the pregnancies experienced by women who had stopped using the IUD were being aborted (Potter et al. 1968: 852), although abortion was illegal at the time. Family planning programs had existed long enough so that the issue of contraceptive failure had to be faced. Dr. K. Kanagaratnam, then chairman of Singapore's Family Planning and Population Board, described the situation: "there was some embarrassment to our clinic personnel when women on the IUD became pregnant and wished their pregnancies to be terminated.... [N] othing much could be done but to urge the women to continue their pregnancy" (1968: 6). The Board recommended that "failed contraception" be made a legal reason for granting a woman a right to abortion. Singapore went on to legalize abortion in 1970.

Abortion, with various duration-of-pregnancy limits and rationales, was also being legalized throughout much of the developed world at the time: 
Great Britain in 1967, Canada in 1969, the United States in 1973, France and Austria in 1975, New Zealand in 1977, and Italy in 1978. In 1972 India liberalized its laws to permit abortions for economic or social reasons during the first 20 weeks of pregnancy. If the international population control movement had not been facing extraordinary challenges in the 1970s, these legalizations might have provoked a second look at its contraception-only definition of family planning. But serious challenges were occurring that largely foreclosed that possibility. In the 1960s national policymakers had embraced family planning for a variety of reasons related to geopolitical circumstances, economic development, resource limitations, maternal health, and illegal abortion. Movement leaders had planned that the World Population Conference at Bucharest in 1974 would be the place where the world would unite behind a single population agenda: lowering high fertility (Finkle and Crane 1975: 87). This, however, did not happen. The movement's family planning agenda did not unite the world, it divided it. The head of the Indian delegation asserted that "development is the best contraceptive" and was greeted with "the acclaim of most Third World participants" (Ford Foundation 1985: 18). Behind that slogan was a questioning of motives, a questioning of why family planning was the one activity for which a Third World government could easily find First World monetary support (Piotrow 1973: 145-158). Developing countries wanted more than contraceptives: they wanted a new world economic order that would bring real development. The "Plan of Action" eventually adopted at Bucharest was a developmentalist one. Population control was not presumed to be a necessary prerequisite for development. Development itself would motivate couples to have small families. As such, a population control policy only made sense if solidly ensconced within a broader policy of economic and social development.

The 1970s proved to be a difficult time for the international population movement. John D. Rockefeller 3rd publicly converted to the developmentalist position at Bucharest (Rockefeller 1974: 4). There was a leadership upheaval at the Population Council. Both the Ford and Rockefeller Foundations reduced their funding for population activities, virtually ending it by 1980. US government spending on population reached major proportions by the early 1970s, more than replacing lost foundation funds, but American presidential politics, largely surrounding the issue of abortion, began to affect how those funds were spent. The politics began even before the 1973 Roe v. Wade Supreme Court decision legalizing abortion in the United States. In 1969 President Richard Nixon called for the establishment of a Commission on Population Growth and the American Future and appointed Rockefeller to head it. Yet when the Rockefeller Commission Report appeared in 1972, calling for state laws to be liberalized to allow "abortion to be performed on request," President Nixon quickly disassociated himself from its findings. He saw "a political opportunity to lure Catholic voters away from the Democratic party" by pursing what the White House called "The Catholic Strat- 
egy" (Critchlow 1996: 14). He denounced Democratic presidential candidate George McGovern for his support for legal access to abortion and won a landslide election victory in 1972. In many ways this strategy became a model followed by future Republican presidential candidates.

Restrictions on family planning funding followed Roe $v$. Wade. That decision spawned a Right-to-Life movement that within two years had become a national organization with significant political strength (Paige 1983) and had aligned itself with the Republican party. Although a constitutional amendment outlawing abortion proved beyond its reach, the movement was able to have laws passed forbidding the use of public funds for abortion and to convince a significant proportion of politicians to publicly oppose abortion. In 1974 explicit abortion restrictions were placed on USAID family planning aid by the amendment of section 114 of the Foreign Assistance Act of 1961 (P.L. 93-189): "None of the funds made available to carry out this part [Part I of the Act] shall be used to pay for the performance of abortions as a method of family planning or to motivate or coerce any person to practice abortions." Passage of the 1974 amendment had practical significance since new abortion techniques were emerging that greatly enhanced the potential utility of abortion as a family planning method (Crane 1994: 245). USAID's Office of Population, then under the direction of the ardent population controller R. T. Ravenholt, had been funding the development of a "Menstrual Regulation Kit" for use in developing countries. Menstrual regulation (also called menstrual extraction, menstrual induction, and endometrial aspiration) was a new procedure performed within two weeks of missed menses using a narrow, flexible plastic suction curette. Women whose missed menses was caused by pregnancy would experience a very early abortion. This procedure is quick, can be performed by paraprofessionals at low cost, and has a very low complication rate. It was first used under field conditions to treat Bangladeshi women who had been raped by Pakistani soldiers during the civil war of 1971. To Ravenholt, at least, it seemed a method of birth regulation ideally suited for integration into developing-world family planning programs; and considering the limited funds then available for support of family planning programs internationally, it was probably the only form of abortion capable of being supported financially by the United States. The 1974 amendment, however, ended USAID involvement in its further development and promotion (National Security Council 1974: Part 2, Section 4, B, "Abortion").

With the US government contributing such a large fraction of international family planning funds, the abortion funding restrictions had a considerable international impact. Still, the decade after Bucharest saw Communist opposition to neo-Malthusianism lessen substantially, more countries establish family planning programs, and the pace of fertility decline accelerate. Some thought that the International Conference on Population held in Mexico City in 1984 might be the occasion at which fertility control was 
universally acclaimed. But American abortion politics prevented consensus from developing. In 1979 the National Right to Life Movement had 11 million members and "the pro-life movement became a major political force in the presidential election of 1980, which put Ronald Reagan into the White House" (Critchlow 1996: 16). In his first term Reagan denounced abortion and appointed bureaucrats to federal agencies with little commitment to a family planning agenda, domestic or international. An international population conference in 1984, an election year, was politically troublesome. Any talk of population problems by Reagan-appointed delegates would be interpreted by anti-abortion social conservatives as opening the door to abortion and state-mandated contraception. Reagan appointed delegates who followed the revisionist views of Julian Simon $(1977,1981)$ by declaring that there was no world population problem. They did, however, believe that the increasing legalization of abortion constituted an international problem. The US delegates voted with the Vatican to amend the Plan of Action to prohibit promoting abortion "as a method of family planning," and used the occasion to announce a new US "Mexico City Policy" aimed at curtailing the spread of abortion. An international NGO wanting family planning funds from USAID, the largest donor source of such funds, had to avoid even the mention of abortion in its programs. This policy made any coordination of population and abortion policies more difficult.

The formulation of international population policy underwent a sea change from 1984 to 1994. Population control lost its salience on the international agenda. Population growth itself was abating, the end of the Cold War had dispelled many of the political fears surrounding such growth, and academic research had lessened worries about its economic effects. The international population control movement lacked ideas for regaining momentum. By the time delegates met at the 1994 Cairo conference, a new direction for the movement had gained force. A group of American reproductive health feminists had been successful in uniting a large bloc of feminists and much of what remained of the population control establishment into a commonground alliance (Hodgson and Watkins 1997). The Programme of Action adopted at Cairo (United Nations 1995) embodied its major terms: redressing gender inequities is needed for lasting fertility control, and women have reproductive rights to freely determine their reproductive destinies. Controversy did erupt over whether the Programme of Action should include abortion in its definition of the "reproductive health care" that all governments should provide. Paragraph 7.6 defines reproductive health care and does include a reference to abortion, but the Vatican, after marshaling enough anti-abortion support among country delegations to place the consensus ratification of the Programme of Action in doubt, succeeded in inserting into the Programme (Paragraph 8.25) the old abortion language of the Mexico City conference: "In no case should abortion be promoted as a method of family planning." The 
advance that reproductive rights advocates achieved was to have Paragraph 8.5 also acknowledge the existence of legal abortion and the need for quality reproductive health care: "In circumstances where abortion is not against the law, such abortion should be safe."

Upon becoming president in 1993 Bill Clinton immediately rescinded Reagan's Mexico City Policy. He restored financing to IPPF and UNFPA, adopted an unequivocal pro-choice position, and went on to ratify US support for reproductive rights goals for the Cairo conference. In the end, though, he had the US delegation go along with the Vatican-inspired compromise on abortion's role in family planning and reproductive health programs. In 1999 pro-life Republican congressmen refused to appropriate funds to pay UN dues and forced from President Clinton a further compromise: a partial reinstatement of some Mexico City Policy restrictions (Schmitt 1999). Upon becoming president in 2001 George W. Bush immediately reinstated the Mexico City Policy in full. He withheld funding from IPPF and UNFPA, adopted an unequivocal pro-life position, and worked with Christian Right groups to increase their presence at international population and women's forums (Butler 2006). For eight years the Bush administration denied funding to any international NGO that provided information, counseling, or referrals about abortion services or that lobbied a government to reform its abortion laws (USAID 2008). It also prohibited any population expert in the US employ from speaking about abortion as a method of family planning. During these years many participants at international population conferences withheld their candid assessments about the appropriate relationship between abortion policy and population policy (Crane and Dusenberry 2004). Because of the desire for consensus when approving "plans of action," and because of the insistence of US representatives that abortion not be discussed as a method of family planning, these plans invariably included the two directives of the common-ground approach: "in no case should [abortion] be promoted as a method of family planning," and the need "to reduce the recourse to abortion through expanded and improved family-planning services." The contemporary appropriateness of these directives, however, was never discussed in an explicit manner.

But even during the Bush years, questions of appropriateness were increasingly being alluded to in international documents and conferences. For instance, in 2003 the World Health Organization published Safe Abortion, a technical guide to help "train and equip health-service providers" in the provision of safe and accessible abortions in countries "where abortion is not against the law." Although noting in its appendix (2003: 100-101) the standard two directives of the common-ground approach, its introductory chapter presented a powerful argument for integrating legal abortion into family planning programs. It made provocative observations, such as that "even where family planning is widely accessible, pregnancies occur due 
to contraceptive failure" (ibid.: 12-13). Such observations seem designed to raise "inappropriate" questions: Why do family planning programs fail to make provisions for the contraceptive failures that are bound to happen in all programs? Where in the Program of Action documents that call on countries to implement family planning programs can one find a section dealing with contraceptive failure? Is there a way other than abortion for an individual, or a family planning program, to deal effectively with contraceptive failure? Back in 1968 when the chairman of Singapore's Family Planning and Population Board faced this issue, he tried to have abortion legalized for the reason of contraceptive failure. Yet would not the suggestion of such a use of abortion at a contemporary international population meeting be problematic since it so clearly entails promoting abortion as a method of family planning?

Safe Abortion went on to quantify the health tragedy associated with the 20 million unsafe, largely illegal abortions occurring each year: 70,000 women dying while "tens of thousands suffer long-term health consequences" (WHO 2003: 7). In a similar fashion, when African ministers of health convened in Maputo, Mozambique in 2006 and produced a Plan of Action on Sexual and Reproductive Health and Rights (African Union Commission 2006: 3), they too presented a dramatic list of unfavorable statistics: " 1 million maternal and newborn deaths annually, an African woman having a 1 in 16 chance of dying while giving birth; high unmet need for family planning with rapid population growth often outstripping economic growth and the growth of basic social services (education and health), thus contributing to the vicious cycle of poverty and ill-health." Such documents that detail adverse population and health statistics-especially those mentioning the high rates of death and disability associated with illegal abortions-all raise additional "inappropriate" questions, even when the common-ground directives are repeated alongside the list. Yet permitting unintended pregnancies to be terminated with a legal abortion, a seemingly obvious response to such statistics, would entail "promoting abortion as a method of family planning." The fact that Safe Abortion, which is after all a WHO technical guide for abortion providers in countries where abortion is legal, would provide such a comprehensive list of the consequences of what are overwhelmingly illegal abortions seems to suggest that the authors of the work were also arriving at that conclusion. The fact that African health ministers in response to their list of adverse statistics went on to recommend (African Union Commission 2006: 13) that every effort be made to "provide safe abortion services to the fullest extent of the law" and to "educate communities on available safe abortion services as allowed by national laws" seems to suggest that they too were drawing "inappropriate" conclusions even while referencing the correctness of Paragraph 8.25 of the Cairo Programme of Action where the common-ground directives about abortion are contained. 


\section{The prospects for a new common-ground approach to abortion and population policy}

More and more documents like the two mentioned at the conclusion of the previous section are seeking to raise significant questions about the appropriateness of the established common-ground approach to abortion, family planning, and population policy. The main contradiction contained in international population conference documents, however, has yet to be confronted. Program of Action population documents since 1984 have urged countries with high fertility to lower it by implementing effective family planning programs while simultaneously maintaining that "in no case should abortion be promoted as a method of family planning," and that governments should "reduce the recourse to abortion through expanded and improved family-planning services." Yet it has been known since the 1960s, and particularly widely known since the 1970s, that countries undergoing the fertility transition can expect, almost without exception, to experience increases in both contraceptive use and induced abortion. These increases in abortion have always involved women using abortion as a means of birth control, and countries experiencing rapid fertility declines have consistently had large increases in abortion. These inconvenient facts have never been addressed at international population conferences. The Cairo+10 documents (UNFPA 2005: 76-77) contain a sophisticated treatment of the stages of the fertility transition as they relate to population aging, and even include policy responses to potential problems. But there has been no treatment of the stages of the fertility transition as they relate to the use of contraception and induced abortion. This is not an inconsequential issue. Sixty-two countries have adopted the Cairo Programme of Action policy suggestions and have a policy to lower fertility while not permitting abortion to be used as a means of family planning (see Table 1). This 27 percent of the world's population has a higher maternal mortality ratio, a higher total fertility rate, and a higher per capita income than the 20 percent of the world's population that is attempting to lower fertility while permitting uncomplicated access to abortion. These inconvenient facts would seem to warrant serious examination by all those interested in reducing maternal mortality.

On 23 January 2009 Barack Obama, as one of his first acts as president, rescinded the Mexico City Policy and stated that he would work to restore US funding for UNFPA (Obama 2009). In his statement he called for "a fresh conversation on family planning, working to find areas of common ground to best meet the needs of women and families at home and around the world." He enunciated a "goal of reducing unintended pregnancies" and noted a need to reduce rates of maternal mortality. Although one of the principal aims of the Mexico City Policy was to exclude abortion from such conversation, President Obama bypassed the question of how he would integrate the topic of abortion into his fresh conversation. Secretary of State Hillary Clinton, 
responding to a question while testifying before the House Foreign Affairs Committee in April, was more explicit about her position on abortion's place in this fresh conversation (France 24 2009):

When I think about the suffering that I have seen of women around the world, I've been in hospitals in Brazil where half the women were enthusiastically and joyfully greeting new babies and the other half were fighting for their lives against botched abortions.... We happen to think that family planning is an important part of women's health, and reproductive health includes access to abortion, that I believe should be safe, legal and rare.

Secretary Clinton's extemporaneous remarks argue for provision of uncomplicated access to safe and legal abortions. Of course, by saying this she has already ignored the first common-ground directive: "in no case should abortion be promoted as a method of family planning."

The United States is still the largest single donor of funds for international family planning, expending approximately \$460 million in FY2009. These funds are likely to increase to well over \$600 million in FY2010 (Fleischman and Moore 2009: 6). The United States had been the most conscientious enforcer of the common-ground approach to abortion for most of the past quarter-century; now it is willing to talk about abortion, family planning, and population policy. These facts guarantee that treatment of this topic will no longer be so firmly bracketed by the two common-ground directives about abortion. With no follow-up international conference on population and development planned after Cairo, it is unclear whether these old directives can be formally changed or rescinded. They can, however, be ignored.

But there remain crucial differences between abortion and contraception. In the past the United States encouraged countries to adopt family planning programs by offering economic incentives for this purpose. It is extremely unlikely the United States would offer any economic encouragements to countries to liberalize their abortion policies. This does not mean, however, that reducing the relevance of the common-ground directives will have no impact on abortion policies. New, open conversation on abortion may lead to change in abortion policies, especially in one set of countries.

Table 2 presents the current combinations of fertility and abortion policies in 179 countries with a population of at least 100,000. Two primary "stress points" in these combinations occur where abortion policies are not structured to further countries' population policies: first, within the 62 countries with a policy to lower fertility that also restrict women's access to abortion; and second, within the 30 countries with a policy to raise fertility that also grant women uncomplicated access to abortion. These stress points raise serious policy concerns to the extent that the lack of integration is the cause of significant problems for the countries involved. When problems occur, lobbying and "education" efforts to promote change in abortion policy may be effective. 
TABLE 2 Cross-tabulation of countries' 2007 fertility policy by whether or not countries permit abortion on request or for economic or social reasons, 2007

\begin{tabular}{|c|c|c|c|c|}
\hline \multirow{2}{*}{$\begin{array}{l}\text { Policy to modify } \\
\text { fertility level }\end{array}$} & \multicolumn{2}{|c|}{$\begin{array}{l}\text { Abortion permitted on } \\
\text { request or for economic } \\
\text { or social reasons }\end{array}$} & \multirow{2}{*}{$\begin{array}{l}\text { Total in } \\
\text { fertility } \\
\text { policy } \\
\text { category }\end{array}$} & \multirow{2}{*}{$\begin{array}{l}\text { Percent } \\
\text { of world } \\
\text { population } \\
\text { in fertility } \\
\text { policy } \\
\text { category }\end{array}$} \\
\hline & Yes & No & & \\
\hline \multicolumn{5}{|l|}{ Lower } \\
\hline Number of countries & 10 & 62 & 72 & \multirow{3}{*}{47} \\
\hline Percent of countries & 14 & 86 & 100 & \\
\hline Percent of population & 43 & 57 & 100 & \\
\hline \multicolumn{5}{|l|}{ Raise } \\
\hline Number of countries & 30 & 7 & 37 & \multirow{3}{*}{13} \\
\hline Percent of countries & 81 & 19 & 100 & \\
\hline Percent of population & 83 & 17 & 100 & \\
\hline \multicolumn{5}{|l|}{ Maintain } \\
\hline Number of countries & 13 & 18 & 31 & \multirow{3}{*}{26} \\
\hline Percent of countries & 42 & 58 & 100 & \\
\hline Percent of population & 88 & 12 & 100 & \\
\hline \multicolumn{5}{|l|}{ No intervention } \\
\hline Number of countries & 14 & 25 & 39 & \multirow{3}{*}{15} \\
\hline Percent of countries & 36 & 64 & 100 & \\
\hline Percent of population & 49 & 51 & 100 & \\
\hline \multicolumn{5}{|l|}{ Total } \\
\hline Number of countries & 67 & 112 & 179 & \multirow{3}{*}{100} \\
\hline Percent of all countries & 37 & 63 & 100 & \\
\hline Percent of world population & 61 & 40 & 100 & \\
\hline
\end{tabular}

SOURCE: See Figure 1.

In the near term the most significant stress point is the first: in countries with a policy to lower fertility and a policy that restricts access to abortion. As discussed earlier, this is a "natural" stress point in that success of the fertility policy would lead to a rapid drop in desired family size and an increase in unwanted pregnancies, even as contraceptive use is increasing. Significant problems would ensue as women with unwanted pregnancies confront the restrictive abortion policy, resort to illegal abortions, and suffer serious health consequences. As was the case in the now low-fertility countries, the likely solution to these problems would be to make illegal abortions into legal ones. Other solutions are difficult to identify. Improving hospital care for women suffering the consequences of illegal abortion is unlikely ever to eliminate the significant health disparities between illegal and legal abortion. Considering the weak state apparatus of most of these countries, enforcement of restrictive abortion laws offers no feasible solution. 
The second stress point is not as significant at the present time, and of uncertain significance in the future. The 30 countries with a policy to raise fertility and a policy that gives women uncomplicated access to abortion have on average a negative annual growth rate (-0.1 percent) and a belowreplacement total fertility rate (1.4). Twenty-four of them are European, of which 12 are now in their third decade of below-replacement fertility. The problematic effects of such low fertility on age structure, social security costs, health care costs, and labor force needs have been widely publicized. They present religious and other opponents of abortion and nationalists worried about the presumed debilitating effects of population decline an opportunity to try to end liberal abortion policies, now held to be a major cause of low fertility. A more restrictive abortion policy, it could be argued, is needed for the social good. To date, such attempts to exploit this stress point have not met with success. In most of these countries the reproductive rights movement has been strong for decades, extensive legislation protects a woman's right to control her fertility, and often a state-supported health care system provides access to contraception and abortion as part of routine medical services (David 1992).

The existence of these two policy stress points illustrates a significant way in which abortion differs from contraception. There is no longer much debate about the nature of contraception or on the proposition that couples have the right to practice contraception to control their fertility. However, substantive debate remains about the nature of induced abortion, and government leaders are far from a consensus about the proposition that all women should have uncomplicated access to abortion. The persistence of different interpretations of abortion, in fact, explains why the stress points referred to above exist and why abortion policies are enacted that do not further the state's fertility policy. Policymakers in a number of low-fertility European countries refuse to consider limiting a woman's access to abortion because they define access to abortion as a woman's right that must be protected by the state. Policymakers in a number of Latin American countries with still comparatively high fertility and active programs to distribute contraceptives refuse to liberalize their highly restrictive abortion policy because they define abortion as the taking of a human life.

The persistence of conflicting views on abortion indicates that cultural, religious, and political traditions still influence the make-up of abortion policies around the world in significant ways. The fact that some 37 percent of the world's population live in countries whose abortion policies are not structured to further their fertility goals is a measure of that influence. Even where states grant women uncomplicated access to abortion, more than a few are making abortion illegal when the intent to abort a pregnancy is based solely on knowledge of the sex of the fetus. In the 1990s China, India, and Vietnam banned the use of ultrasonography and other techniques to identify the sex of fetuses for purposes of abortion. More recently China, Nepal, and Italy have 
simply outlawed abortion for purposes of sex selection (Boland and Katzive 2008: 111-113), and more countries are considering such legislation. With respect to abortion, therefore, there is an ongoing debate as to whether the state should protect an individual right or a perceived social interest. With respect to contraception such debates are largely things of the past. Reproductive rights advocates find this particular abortion debate especially unsettling. All find sex-selective abortion of female fetuses morally reprehensible, but not all agree that it should be outlawed. Many, in fact, "are convinced that outlawing sex-selective abortion will undermine the reproductive rights of women" (Chamie 2008).

If a Program of Action is drafted at some future international conference on population, say in 2024, what would constitute a defensible common-ground approach to abortion, family planning, and population policy? Arguably, such an approach will still be needed. The divergent viewpoints on abortion associated with religious and cultural traditions show no sign of disappearing and are likely to determine the positions of policymakers well into the future. Policy is always made at the national level and the most that a conference on population can achieve is to arrive at a set of recommendations that might encourage countries to bend policies in the direction of some higher principles rather than simply reflecting prevailing national interests. Cairo's Programme of Action focused on furthering reproductive health and on ensuring that women have the central role in determining their own fertility. That the representatives of scores of countries pledged to formulate their population policies in light of these higher principles is widely seen as Cairo's greatest accomplishment. Preserving these goals would no doubt be central to any new Program of Action. What was problematic about Cairo's common-ground directives, however, was that they also implicitly acknowledged another higher principle - that fetuses have rights that place limits on a woman's right to control her fertility-which actively thwarted the pursuit of these goals in major ways. They made it difficult to discuss pressing issues that affect the health and reproductive rights of millions of women: how to deal with contraceptive failure and how to deal in a healthful way with the millions of unwanted pregnancies associated with populations rapidly undergoing their fertility transitions. At international forums powerful actors used these directives to preclude discussion of the role that liberalizing access to abortion might play in advancing the goals of reproductive health and reproductive rights. The United States in particular used its position as the largest single donor of funds for international family planning programs to inhibit discussion of abortion outside of international forums, compounding the setback to reproductive rights goals.

A lesson from the Cairo experience is that the worldwide liberalization of abortion policy serves to enhance reproductive health and reproductive rights only if the states adopting more liberal abortion policies actually have a com- 
mitment to furthering reproductive health and reproductive rights. This has not always been the case. In 1972 India liberalized its abortion policy to permit abortion for economic or social reasons but then in 1976 initiated a forced sterilization campaign. China has allowed abortion on request for decades, but has also coerced women with wanted pregnancies to undergo abortions (Connelly 2008). A country's commitment to reproductive health and reproductive rights cannot necessarily be measured by its policy on abortion.

The reproductive rights movement took hold when most countries were still focused on the need to lower fertility. Reproductive rights advocates wanted to enhance women's ability to control their fertility, and states wanted to lower birth rates. There was a meshing of interests in that giving women greater access to birth control promised to accomplish both goals. The problem with this close linkage for reproductive rights advocates, one addressed in previous Program of Action documents, was how to rein in state enthusiasm for fertility control so that women would not be forced to have smaller families than they wanted. As the twenty-first century progresses there will be less and less linkage between state and movement interests. A growing number of states will experience low fertility and will adopt policies to increase it. Since this "problematic" low fertility is commonly accepted as an expression of the actual fertility desires of women, given their social and economic circumstances, there will be much greater potential for direct conflict between state goals and movement goals. Can states induce higher fertility while still respecting the reproductive rights of women? Doing so without coercion requires authentic state commitment to principles of reproductive rights. European states have generally implemented pronatalist policies by seeking to ensure that every woman has the means to have all the children that she desires. They have instituted programs that allow women to more easily participate in the labor force and have children, or that provide them with a portion of the costs associated with rearing a child. Such programs, sensitive to reproductive rights issues, are expensive and so far have not proven especially effective. What will happen when more states with a weaker commitment to reproductive rights principles seek to increase their fertility? States can undertake, and have undertaken, unilateral changes in fertility and abortion policies that suddenly strip women of access to both contraception and abortion, the most notorious example being Communist Romania's 23-year experiment in seeking to raise the birth rate (Baban 1999). A low-fertility future promises significant new challenges that can only be effectively dealt with by a continuing attention to women's reproductive rights.

What of the common-ground approach being sought by the Obama administration: the goal of making abortion safe, legal, and rare? Domestically, it is by no means clear that the gulf between pro-life and pro-choice advocates can be bridged by that formulation. Early signs are not encouraging. Internationally, there are fertility and family formation trends that will make "rareness" 
difficult to achieve: fertility is continuing to fall significantly, and marriage and childbearing are taking place at later ages. An increasing portion of the world's women are finding themselves in a situation comparable to that currently experienced by women in developed countries: sexual activity is initiated well before children are wanted; childbearing is postponed to later ages; and the desired number of children is falling to low levels. More women, therefore, are finding themselves with an increasing number of years in which they are fecund and sexually active but want no children. Abortion has played a far from trivial role in how women in industrialized countries have accomplished and are accomplishing their new fertility goals: currently women in developed countries, compared to those in developing countries, have both a higher fraction of pregnancies that are said to be unintended ( 56 percent vs. 42 percent) and a higher fraction of all pregnancies ending in abortion (41 percent vs. 23 percent) (Bongaarts and Westoff 2000: 194). This is true even though contraceptive prevalence rates are considerably higher in developed countries. Therefore, it is difficult to see how abortion can be expected to become "rare" internationally as more of the world's women adopt this new fertility regime.

Absent the condition of rarity, the issue of legality (and thereby safety) of abortion will remain prominent, and those negotiating a new commonground approach to abortion, family planning, and population policy in the international arena will face substantial challenges. In the near term it seems likely that the commitment to reproductive health and reproductive rights will gradually spread to more countries, with "common ground" attained mainly by the weakening of opposition to legal access to abortion, if under varying degrees of constraint. However, ensuring that individual women have the central role in determining their own fertility is not something that can be accomplished once and for all, especially in light of the spread of belowreplacement fertility. It is a goal that each generation has to struggle to attain for itself.

\section{Notes}

I thank all the anonymous reviewers for their many insightful comments, criticisms, additional references, and suggested changes. The end result is an article that is quite different from the initial version, and one that is much improved.

1 The accuracy of the figures for legal abortions is open to question. A recent press report from the state-run newspaper China Daily (2009) states that 13 million abortions are performed each year in China, and suggests that "the real number of abortions is much higher than reported." This estimate of 13 million abortions is considerably higher than the 7,215,000 reported for 2003 by Sedge et al., although that number was "obtained from the Ministry of Health" (2007b: 111). Interestingly, both sources caution that since medication abortions and many abortions performed at private clinics are missing from official counts, their reported numbers are likely to be significant undercounts.

2 The WHO ultimately classifies "unsafe" abortions as "illegal" abortions (2007: 7): “The relative safety of unsafe abortion differs by country depending on the skills of the providers and the methods used, but is also linked to the de facto application of the law. The 
estimates given in this document are intended to reflect induced abortions that carry greater risks than those carried out officially for reasons accepted in the laws of a country."

3 The ten Latin American/Caribbean countries with antinatalist policies and restricted access to abortion are Colombia, Costa Rica, Dominican Republic, Guatemala, Haiti, Honduras, Jamaica, Mexico, Nicaragua, and Peru.

4 The three African countries with antinatalist policies and uncomplicated access to abortion are Cape Verde, Tunisia, and Zambia; the 35 African countries with antinatalist policies and restricted access to abortion are Algeria, Benin, Burkina Faso, Burundi, Cameroon, Comoros, Congo, Egypt, Eritrea, Ethiopia, Gambia, Ghana, Guinea, Ivory Coast, Kenya, Lesotho, Liberia, Madagascar, Malawi, Mali, Mauritania, Morocco, Mozambique, Namibia, Niger, Nigeria, Rwanda, Senegal, Sierra Leone, Sudan, Swaziland, Tanzania, Togo, Uganda, and Zimbabwe.

5 The ten countries with an antinatalist policy and uncomplicated access to abortion are Bahrain, Cambodia, Cape Verde, Fiji, India, Nepal, Tajikistan, Tunisia, Vietnam, and Zambia. The 62 countries with an antinatalist fertility policy and restricted access to abortion are Algeria, Bangladesh, Benin, Bhutan, Burkina Faso, Burundi, Cameroon, Colombia, Comoros, Congo, Costa Rica, Dominican Republic, Egypt, Eritrea, Ethiopia, Gambia, Ghana, Guatemala, Guinea, Haiti, Honduras, Indonesia, Iran, Ivory Coast, Jamaica, Jordan, Kenya, Laos, Lebanon, Lesotho, Liberia, Madagascar, Malawi, Maldives, Mali, Mau- ritania, Mexico, Micronesia, Morocco, Mozambique, Namibia, Nicaragua, Niger, Nigeria, Oman, Pakistan, Papua New Guinea, Peru, Philippines, Rwanda, Samoa, Senegal, Sierra Leone, Solomon Islands, Sudan, Swaziland, Tanzania, Togo, Uganda, Vanuatu, Yemen, and Zimbabwe.

6 The woman, though, actually determines whether she is in distress (UN 2002: 150): "The law requires a woman seeking an abortion to state that she is in a state of distress as a result of her situation; the decision to have an abortion, however, is entirely the decision of the woman."

7 The number of abortions in France has remained remarkably constant since legalization, at around 200,000 annually (Bajos et al. 2004). Interestingly, this has happened even as more women began using the pill and the IUD and as the percent of pregnancies that were unplanned fell from 46 percent in 1975 to 33 percent in 2000. The numbers of abortions did not decline, because women were deciding to terminate an increasing percentage of their unplanned pregnancies: 62 percent in 2000 compared to 41 percent in 1975. Women's increased tendency to terminate an unwanted pregnancy was associated with their "sharply rising school enrolment and labour force participation rates" (ibid.: 2). France's experience illustrates that the relationship between contraceptive use and abortion can be a complicated one. The same factors that prompt women to employ more effective contraception might also prompt them to terminate a higher percentage of unwanted pregnancies.

\section{References}

Accampo, Elinor A. 2003. "The gendered nature of contraception in France: Neo-Malthusianism, 1900-1920," Journal of Interdisciplinary History 34(2): 235-262.

African Union Commission. 2006. Plan of Action on Sexual and Reproductive Health and Rights (Maputo Plan of Action). Addis Ababa, Ethiopia. «http://www.unfpa.org/africa/newdocs/ maputo_eng.pdf».

Baban, Adriana. 1999. "Romania," in Henry P. David and Joanna Skilogianis (eds.), From Abortion to Contraception: A Resource to Public Policies and Reproductive Behavior in Central and Eastern Europe from 1917 to the Present. Westport, CT: Greenwood Press, pp. 191-222.

Bajos, Nathalie, Caroline Moreau, Henri Leridon, and Michèle Ferrand. 2004. "Why has the number of abortions not declined in France over the past 30 years?" Population $\theta$ Societies 407: 1-4.«http://www.ined.fr/fichier/t_publication/69/publi_pdf2_pop.and.soc.english.407.pdf». 
Balfour, M. C. 1961. "Family planning in Asia," Population Studies 15(2): 102-109.

Blake, Judith. 1963. "Pioneering in family planning," Milbank Memorial Fund Quarterly 41(3): 319-323.

Boland, Reed and Laura Katzive. 2008. "Developments in laws on induced abortion: 19982007," International Family Planning Perspectives 34(3): 110-120.

Bongaarts, John and Charles F. Westoff. 2000. “ The potential role of contraception in reducing abortion," Studies in Family Planning 31(3): 193-202.

Butler, Jennifer S. 2006. Born Again: The Christian Right Globalized. London: Pluto Press.

Chamie, Joseph. 2008. "The global abortion bind," YaleGlobal Online (29 May) «http://yaleglobal. yale.edu/display.article?id=10886".

Chesler, Ellen. 1992. Woman of Valor: Margaret Sanger and the Birth Control Movement in America. New York: Simon \& Schuster.

China Daily. 2009. "Abortion statistics cause for concern," China Daily, 30 July «http://www. chinadaily.com.cn/china/2009-07/30/content_8489656.htm».

Coale, Ansley J. and Edgar M. Hoover. 1958. Population Growth and Economic Development in Low-Income Countries. Princeton: Princeton University Press.

Connelly, Matthew. 2008. Fatal Misconception: The Struggle to Control World Population. Cambridge, MA: Belknap Press.

Crane, Barbara B. 1994. "The transnational politics of abortion," Population and Development Review 20(Supp.): 241-262.

Crane, Barbara B. and Jennifer Dusenberry. 2004. "Power and politics in international funding for reproductive health: The US global gag rule," Reproductive Health Matters 12(24): 128-137.

Critchlow, Donald T. (ed.). 1996. The Politics of Abortion and Birth Control in Historical Perspective. University Park, PA: Penn State Press.

- 2001. Intended Consequences: Birth Control, Abortion, and the Federal Government in Modern America. New York: Oxford University Press.

David, Henry P. 1992. "Abortion in Europe, 1920-91: A public health perspective," Studies in Family Planning 23(1): 1-22.

Davis, Kingsley. 1963. "The theory of change and response in modern demographic history," Population Index 29(4): 345-366.

- 1967. "Population policy: Will current programs succeed?," Science 158(3802): 730739.

Davis, Kingsley and Judith Blake. 1956. "Social structure and fertility: An analytic framework," Economic Development and Cultural Change 4(3): $211-235$.

Debré, Robert and Alfred Sauvy. 1946. Des Français pour la France. Paris: Gallimard.

Dore, R. P. 1953. "Japanese rural fertility: Some social and economic factors," Population Studies 7(1): 62-88.

Faundes-Latham, Anibal, German Rodriguez-Galant, and Onofre Avendano-Portius. 1968. “Effects of a family planning program on the fertility of a marginal working-class community in Santiago," Demography 5(1): 122-137.

Finkle, Jason L. and Barbara B. Crane. 1975. “The politics of Bucharest: Population, development, and the new international economic order," Population and Development Review $1(1)$ : 87-114.

Fleischman, Janet and Allen Moore. 2009. International Family Planning: A Common-Ground Approach to an Expanded U.S. Role. Washington, DC: Center for Strategic and International Studies «http://csis.org/files/publication/090723_Fleischman_IntlFamilyPlng.pdf».

Ford Foundation. 1985. “The Ford Foundation's work in population," Ford Foundation Working Paper, New York.

France 24. 2009. "Clinton defends US decision to finance global family planning," 23 April «http://www.france24.com/en/20090423-clinton-usa-obama-administration-financingfamily-planning-abortion".

Frejka, Tomas. 1985. "Induced abortion and fertility," Family Planning Perspectives 17(5): 230-234. 
Gelb, Joyce. 1996. "Abortion and reproductive choice: Policy and politics in Japan," in Marianne Githens and Dorothy McBride Stetson (eds.), Abortion Politics: Public Policy in Cross-Cultural Perspective. New York: Routledge, pp. 119-138.

Gray, Madeline. 1979. Margaret Sanger: A Biography of the Champion of Birth Control. New York: Richard Marek Publishers.

Harkavy, Oscar. 1995. Curbing Population Growth: An Insider's Perspective on the Population Movement. New York: Plenum Press.

Himes, Norman E. 1932. "Birth control in historical and clinical perspective," Annals of the American Academy of Political and Social Science 160(March): 49-65.

Hodgson, Dennis. 1983. "Demography as social science and policy science," Population and Development Review 9(1): 1-34.

Hodgson, Dennis and Susan Cotts Watkins. 1997. "Feminists and neo-Malthusians: Past and present alliances," Population and Development Review 23(3): 469-523.

INEE (Institut national de la statistique et des études économiques). 2009. "Tableau 34-Nés Vivants Et Enfants Sans Vie Selon La Situation Matrimoniale Des Parents (Territoire Actuel." «http://www.insee.fr/fr/ppp/bases-de-donnees/irweb/sd20071/dd/excel/ sd20071_t34_fm.xls".

Kanagaratnam, K. 1968. "Singapore: The National Family Planning Program," Studies in Family Planning 1(28): 1-11.

Kihara, Masako Ono, Jane S. Kramer, Deborah Bain, Masahiro Kihara, and Jeff Mandel. 2001. "Knowledge of and attitudes toward the pill: Results of a national survey in Japan," Family Planning Perspectives 33(3): 123-127.

Koos, Cheryl A. 1999. “'On les Aura!': The gendered politics of abortion and the Alliance Nationale Contre la Depopulation, 1938-1944," Modern and Contemporary France 7(1): 21-33.

Latham, Melanie. 2002. Regulating Reproduction: A Century of Conflict in Britain and France. Manchester: Manchester University Press.

Measham, Anthony R. 1975. "Latin America 1974: An overview," Studies in Family Planning 6(8): 281-282.

Morris, John D. 1959. "Asserts issue is religious and should not enter realm of politics," New York Times, 3 December: 1, 20.

National Security Council. 1974. Implications of Worldwide Population Growth for U.S. Security and Overseas Interests. National Security Study Memorandum 200. Washington, DC: National Security Council.

Norgren, Tiana. 2001. Abortion before Birth Control: The Politics of Reproduction in Postwar Japan. Princeton: Princeton University Press.

Oakley, Deborah. 1978. "American-Japanese interaction in the development of population policy in Japan, 1945-52," Population and Development Review 4(4): 617-643.

Obama, Barack. 2009. "Statement of President Barack Obama on rescinding the Mexico City Policy" «http://www.usaid.gov/our_work/global_health/pop/obama_statement_mcp.pdf».

Ogawa, Naohiro. 2003. "Japan's changing fertility mechanisms and its policy responses," Journal of Population Research (20) 1: 89-106.

Paige, Connie. 1983. The Right to Lifers. New York: Summit Books.

Piotrow, Phyllis Tilson. 1973. World Population Crisis: The United States Response. New York: Praeger.

Potter, Robert G., Ronald Freedman, and Lien-Ping Chow. 1968. “Taiwan's family planning program," Science, New Series 160(3830): 848-853.

Potts, Malcolm, Peter Diggory, and John Peel. 1977. Abortion. New York: Cambridge University Press.

Requena, Mariano. 1968. "The problem of induced abortion in Latin America," Demography 5(2): 785-799.

- 1970. “ Abortion in Latin America," in Robert E. Hall (ed.), Abortion in a Changing World, Vol. 1. New York: Columbia University Press.

Requena, Mariano and Tegualda Monreal. 1968. "Evaluation of induced abortion control," Milbank Memorial Fund Quarterly 46(3), Part II: 191-218. 
Rockefeller, John D. 3rd. 1974. "Population growth: The role of the developed world," Lecture Series on Population. Liège: International Union for the Scientific Study of Population.

Sauvy, Alfred. 1945. Richesse et Population. Paris: Payot.

Schmitt, Eric. 1999. "Deal on U.N. dues breaks an impasse and draws critics," New York Times, 16 November.

Sedgh, Gilda, Stanley K. Henshaw, Susheela Singh, Elisabeth Åhman, and Iqbal H Shah. 2007a. "Induced abortion: Estimated rates and trends worldwide," Lancet 370(13 October): 1338-1345.

Sedgh, Gilda, Stanley K. Henshaw, Susheela Singh, Akinrinola Bankole, and Joanna Drescher. 2007b. "Legal abortion worldwide: Incidence and recent trends," International Family Planning Perspectives 33(3): 106-116.

Simon, Julian L. 1977. The Economics of Population Growth. Princeton: Princeton University Press.

. 1981. The Ultimate Resource. Princeton: Princeton University Press.

Stycos, J. Mayone. 1964. "Survey research and population control in Latin America," Public Opinion Quarterly 28(3): 367-372.

. 1967. "Politics and population control in Latin America," World Politics 20(1): 66-82.

Sutter, Jean. 1950. Résultats d'une enquête sur l'avortement dans la région parisienne," Population 5(1): 77-102.

Taeuber, Irene B. 1956. "Recent population developments in Japan: Some facts and reflections," Pacific Affairs 29(1): 21-36.

. 1958. The Population of Japan. Princeton: Princeton University Press.

UNFPA. 2005. ICPD: The World Reaffirms Cairo. New York: United Nations Population Fund.

United Nations. 1964. Asian Population Conference (1963: Delhi): Report and Selected Papers. Document E/CN.11/670. New York: United Nations.

- 1984. "Recommendations for the further implementation of the World Population Plan of Action," Population and Development Review 10(4): 758-782.

- 1995. Report of the International Conference on Population and Development, Cairo, 5-13 September 1994. A/Conf.171/13/Rev.1. New York: United Nations. «http://www.unfpa. org/upload/lib_pub_file/570_filename_finalreport_icpd_eng.pdf».

_. 1999. "The United Nations on the implementation of the Cairo Program of Action," Population and Development Review 25(3): 613-634.

- 2000. Demographic Yearbook: Historical Supplement. ST/ESA/STAT/SER.R/CD/28. New York: United Nations.

United Nations, Department of Economic and Social Affairs. 2002. Abortion Policies: A Global Review, Vols. 1-3 (E.01.XIII.10); E.01.XIII.18; E.02.XIII.5). New York: United Nations "http://www.un.org/esa/population/publications/abortion/».

United Nations Population Division. 2008. World Population Policies 2007 (ST/ESA/SER.A/272). New York: United Nations. «http://www.un.org/esa/population/publications/wpp2007/ wpp2007.htm».

USAID. 2008. “USAID's family planning guiding principles and U.S. legislative and policy requirements," last updated 10 April 2008 «http://www.usaid.gov/our_work/global_health/ pop/restrictions.html».

Vincent, Paul. 1950. "La famille normale," Population 5(2): 251-269.

Watson, Cicely. 1952. "Birth control and abortion in France since 1939," Population Studies 5(3): 261-286.

- 1954. "Population policy in France: Family allowances and other benefits, I," Population Studies 7(3): 263-286.

Whelpton, P. K. 1950. "The outlook for the control of human fertility in Japan," American Sociological Review 15(1): 34-42.

World Health Organization. 2003. Safe Abortion: Technical and Policy Guidance for Health Systems. Geneva: World Health Organization.

. 2007. Unsafe Abortion: Global and Regional Estimates of the Incidence of Unsafe Abortion and Associated Mortality in 2003, 5th edition. Geneva: World Health Organization. 